\title{
A History of Major Hanford Facilities and Processes Involving Radioactive Material
}
M. Y. Ballinger
R. B. Hall

March 1991
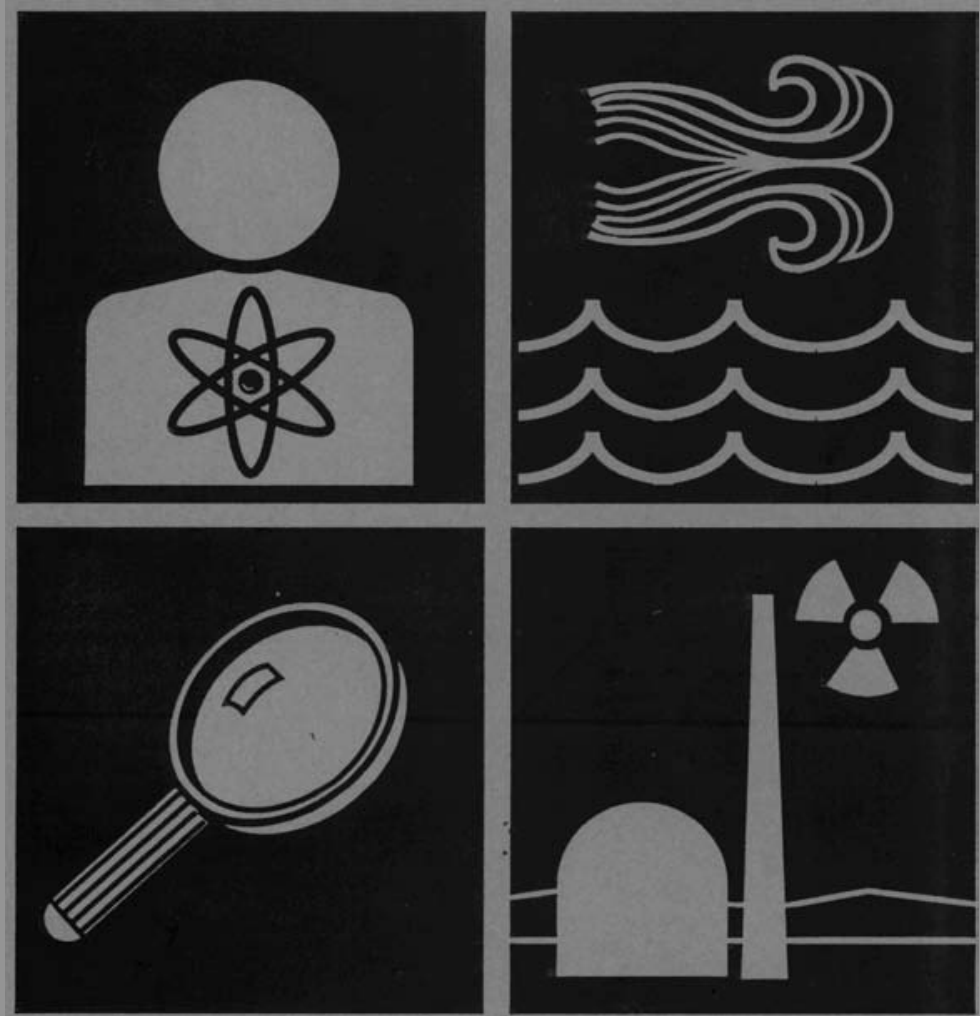

Prepared for the Technical Steering Panel

\% Battelle 


\section{DISCLAIMER}

This report was prepared under the direction of the HANFORD ENVIRONMENTAL DOSE RECONSTRUCTION PROJECTTechnical Steering Panel by Battelle Memorial Institute's Pacific Northwest Laboratories operating the Pacific Northwest Laboratory for the U.S. Department of Energy (DOE). While funding for the work was provided by DOE, the work is not under DOE direction or control. The views and opinions of the authors expressed in this document do not necessarily reflect those of the United States Government or any agency thereof. Reference herein to any specific commercial product, process or service by trade name, trademark, manufactureror otherwise does not necessarily constitute or imply its endorsement, recommendation or favoring by the U.S. Government or any agency thereof, nor by Battelle Memorial Institute.

Printed in the United States of America

Available to DOE and DOE contractors from the

Office of Scientific and Technical Information, P.O. Box 62, Oak Ridge, TN 37831; prices available from (615) 576-8401. FIS 626-8401.

Available to the public from the National Technical Information Service, U.S. Department of Commerce, 5285 Port Royal Rd., Springfield, VA 22161. 


\section{A HISTORY OF MAOR HANFORD FACILITIES AND PROCESSES INVOLVING RADIOACTIVE MATERIAL}

Hanford Environmental Dose

Reconstruction Project

M. Y. Ballinger

R. B. Hall

March 1991

Prepared for the

Technical Steering Panel

Pacific Northwest Laboratory

Richland, Washington 99352 


\section{A HISTORY OF MAJOR HANFORD FACILITIES AND PROCESSES INVOLVING RADIOACTIVE MATERIAL}

March 1991

This document has been reviewed

and approved by the Technical Steering Panel.

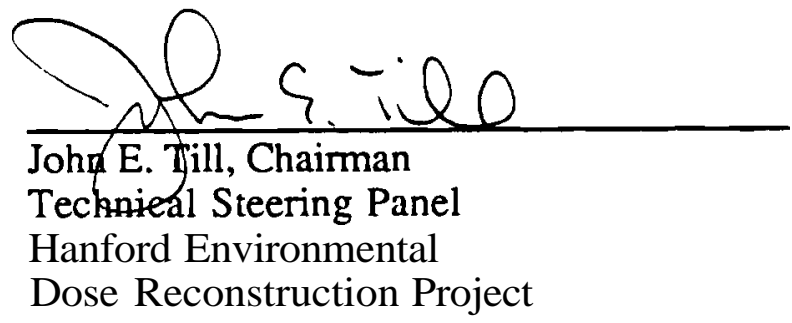

$\frac{\text { March } 7 \text { 1991 }}{\text { Date }}$

Dose Reconstruction Project 


\section{$\underline{\text { ABSTRACT }}$}

The Hanford Environmental Dose Reconstruction (HEDR) Project was established in 1987 to estimate radiation doses that people could have received from nuclear operations at the Hanford Site since 1944. Hanford Site operations began in 1944 to produce plutonium for nuclear weapons. This effort included fabricating fuel elements, irradiating the fuel in nuclear reactors, and separating the resulting plutonium from uranium and fission byproducts.

To build a foundation for the first step in estimating radiation doses-estimating the amount and type of radioactive materials released to the environment--HEDR staff at the Pacific Northwest Laboratory compiled and summarized historical information that describes the processes and facilities in which radioactive material was generated or used at the Hanford Site. This document categorizes nuclear operations under six processes: fuel fabrication, reactor operations, fuel separations, plutonium finishing, research and development, and tank farms and waste recovery. Historical emission controls and effluent monitoring are discussed for each process.

The time period under study ranges from the startup of nuclear operations in 1944 to the present; this report emphasizes the earlier years from 1944 to the mid-1960s. Timetables are provided for each operation to identify operational periods and major changes that may have affected the release of radionuclides to the environment.

Because Hanford Site operations used the first large-scale nuclear facilities of their kind, process development and effluent control measures evolved as knowledge about the processes improved. Over the years, facilities were added or modified to improve processes, accelerate production, and better control emissions to the environment. Changes in each of these areas influenced the quantity and types of radioactive contaminants released to the environment. Separate HEDR documents contain estimates of the quantities of these radioactive contaminants. 


\section{FOREWORD}

The appendix to this document is a record of TSP comments and Battelle's responses; the TSP has reviewed and approved Battelle's responses to its comments. The comment numbers appear in the left margin next to the paragraph in which the corresponding comment was addressed. Changed text is shown in italics. In addition to TSP comments, some changes were made to correct errors or for further clarification. 


\section{CONTENTS}

FOREWORD . . . ..................... . .

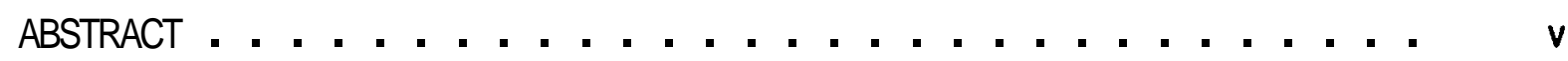

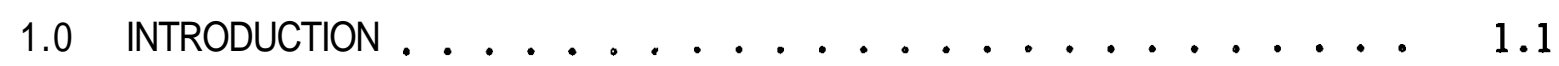

2.0 FUEL FABRICATION . . . . . . . . . . . . . 2.1

2.1 PROCESS DESCRIPTION . . . . . . . . . . 2.1

2.1.1 As uminum-Clad Fuel . . . . . . . . . . . 2.2

2.1.2 Zirconium-Clad Fuel .......... 2.3

2.2 FACILITY DESCRIPTION . . . . . . . . . . 2.4

2.2.1 Aluminum-Clad Fuel . . . . . . . . . . . 2.4

2.2.2 Zirconium-Clad Fuel . . . . . . . 2.6

2.3 TIMETABLE . . . . . . . . . . . . . . . 2.6

2.4 EFFLUENTS . . . . . . . . . . . . . . . . 2.7

3.0 REACTOR OPERATIONS ........................... 3.1

3.1 PILE REACTIONS AND SUPPORT SYSTEMS . . . . . . . . . 3.1

3.2 FACILITY DESCRIPTION . . . . . . . . . . . 3.3

3.2 .1 Pile Design . . . . . . . . . . . 3.3

3.2.2 Pile Controls . . . . . . . . . . . 3.6

3.2.3 Cooling Water System . . . . . . . . 3.7

3.2.4 Helium System . . . . . . . . . . . 3.8

3.3 REACTOR DIFFERENCES . . . . . . . . . . 3.10

3.4 FUELSTORAGE . . . . . . . . . . . . . 3.13

3.5 TIMETABLE . . . . . . . . . . . . . 3.14

3.6 EFFLUENTS . . . . . . . . . . . . . . . . . . . 3.17

4.0 FUEL SEPARATIONS ....................... 4.1 
4.1 PROCESSDESCRIPTIONS . . . . . . . . . . . . . 4.1

4.1.1 Bismuth Phosphate Process . . . . . . . . 4.2

4.1 .2 REDOX Process ............. 4.5

4.1 .3 PUREX Process . . . . . . . . . . . . . 4.6

4.1 .4 TBP Process . . . . . . . . . . . . 4.6

4.2 FACILITY DESCRIPTIONS . . . . . . . . . . . . 4.6

$4.2 .1 \quad$ B and T Plants . . . . . . . . . . . 4.7

4.2.2 224 Concentration Building . . . . . . . . 4.9

4.2 .3 REDOX Plant . . . . . . . . . . . 4.13

4.2 .4 PUREX Plant . . . . . . . . . . . . 4.15

4.2 .5 C Plant ................ . . 4.18

$4.2 .6 \mathrm{U}$ and $\mathrm{UO}_{3}$ Plants................ 4.18

4.3 TIMETABLE . . . . . . . . . . . . . . . 4.19

4.4 EFFLUENTS . . . . . . . . . . . . . . . 4.21

4.4.1 Gaseous Waste . . . . . . . . . . 4.21

4.4.2 Aqueous Waste ............. . . 4.23

5.0 PLUTONIUM FINISHING . . . . . . . . . . . . . . . 5.1

5.1 PROCESS DESCRIPTION . . . . . . . . . . . 5.1

5.2 FACILITY DESCRIPTION . . . . . . . . . . . . . 5.1

5.3 TIMETABLE .......................... 5.3

5.4 EFFLUENTS ............................. 5.4

6.0 RESEARCH AND DEVELOPMENT . . . . . . . . . . . . 6.1

6.1325 BUILDING . . . . . . . . . . . . . . . . 6.2

6.2327 BUILding . . . . . . . . . . . . . . . . 6.3

$6.3308 / 309$ BUILDINGS . . . . . . . . . . . 6.3

6.4324 BUILDING . . . . . . . . . . . . . . . 6.4 
6.5 CRITICAL MASS LABORATORIES . . . . . . . . 6.5

6.6 TRITIUM EXTRACTION FACILITIES . . . . . . . . 6.5

7.0 TANK FARMS AND WASTE RECOVERY . . . . . . . . . 7.1

7.1 TANKFARMS ...................... 7.1

7.2 WASTE RECOVERY . . . . . . . . . . . 7.3

8.0 REFERENCES . . . . . . . . . . . . . . . . 8.1

9.0 GLOSSARY . . . . . . . . . . . . . . . . . 9.1 APPENDIX - SUMMARY OF TSP COMMENTS AND BATTELLE RESPONSES . . . . A.1 


\section{FIGURES}

1.1 Hanford Site . . . . . . . . . . . . 1.2

1.2 Operating Periods for Major Hanford Facilities . . . . . . 1.3

2.1 Zirconium-Clad Fuel Design . . . . . . . . . . 2.4

2.2 Fuel Manufacturing Facilities in the 300 Area . . . . . 2.5

3.1 Cross Section of a Uranium Column in a Pile . . . . . 3.3

3.2 Reactor Shields and Inert Gas Atmosphere . . . . . . . . 3.5

3.3 Cross Section of Control Rod and Hole ... . . . . . 3.7

3.4 100-D Area Water System . . . . . . . . . . 3.9

3.5 Flow Chart for Helium System ............. 3.11

3.6 Location of Reactor Areas on the Hanford Site . . . . . 3.12

3.7 Operating Periods for Hanford Reactors . . . . . . . . . 3.15

3.8 Air Flow Through C Reactor . . . . . . . . . . . . 3.20

3.9 Reactor Effluent System Flow Diagram . . . . . . . . . 3.21

4.1 Process Used in B and T Plants . . . . . . . . . . . 4.3

4.2 Isometric Diagram of B and T Plant Canyon ....... 4.7

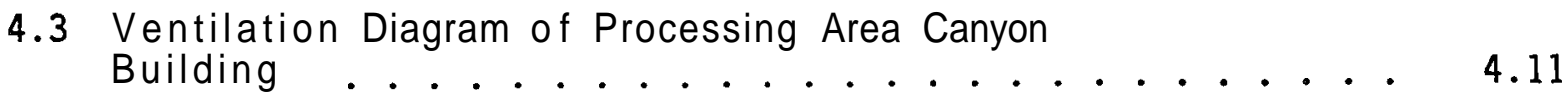

4.4 REDOX Plant Simpli fied Layout . . . . . . . . . . . . . 4.14

4.5 Top-Down View of the PUREX Plant . . . . . . . . . . 4.16

4.6 Isometric View of PUREX Plant . . . . . . . . . . . 4.17

4.7 Uranium Recovery and $\mathrm{UO}_{3}$ Plants ............ 4.20

4.8 Typical Ground Disposal Facilities . . . . . . . . . . . . 4.24

5.1 Location of Plutonium Finishing Operations . . . . . . 5.2

7.1 Typical High-Level Waste Storage Facility . . . . . 7.2 


\section{$\underline{\text { TABLES }}$}

3.1 Fuel and Target Element Failures in Hanford Reactors . . . 3.18

4.1 Functions of Cells for B and T Plants ......... 4.10

4.2 Functions of Cells in Concentration Building ....... 4.12 


\subsection{INTRODUCTION}

In 1943, the U.S. Army Corps of Engineers selected an area of about 600 square miles, in semiarid southeastern Washington State, for producing pl utoni um and other nuclear materials supporting weapons production for World War II. This area, called the Hanford Site, was divided into three major operational areas supporting plutonium production (Figure 1.1). These areas were the 100 Areas for reactor operations (shown in Figure 1.1 as 100-B, 100-C, etc.), the 200 Areas for fuel reprocessing, plutonium recovery, and waste management, and the 300 Area for fuel fabrication. Nine nuclear reactors for the production of plutonium were eventually constructed in the 100 Areas (Figure 1.2). Reactor operations began in 1944; the last production reactor was put in cold standby in 1987. Support facilities were constructed in the 200 and 300 Areas in the 1940s and 1950s; some of these facilities continue to operate. Hanford Site operations developed and changed as the defense needs of the United States and the understanding of nuclear energy changed. Health physics and environmental monitoring activities at the Hanford Site developed through the years as well, impacting the quantity and types of radioactive materials released to the envi ronment.

The Hanford Environmental Dose Reconstruction (HEDR) Project was established to estimate the radiological dose impact Hanford operations may have made on the local and regional population. This impact is estimated by examining operations involving radioactive materials that were conducted at the Hanford Site from the startup of the first reactor in 1944 to the present. The probable quantities of emissions from each facility to the air, water, and ground can be identified from measurements taken by monitoring groups or can be calculated by computing the amount of radionuclides present in each facility's process and applying release factors to the result. Radiation doses can be estimated from these emissions by accounting for specific radionuclide transport conditions and population demography.

Pacific Northwest Laboratory (PNL) is conducting the HEDR Project under the direction of an independent Technical Steering Panel, which is composed of experts in various fields required by the study. The technical members of 


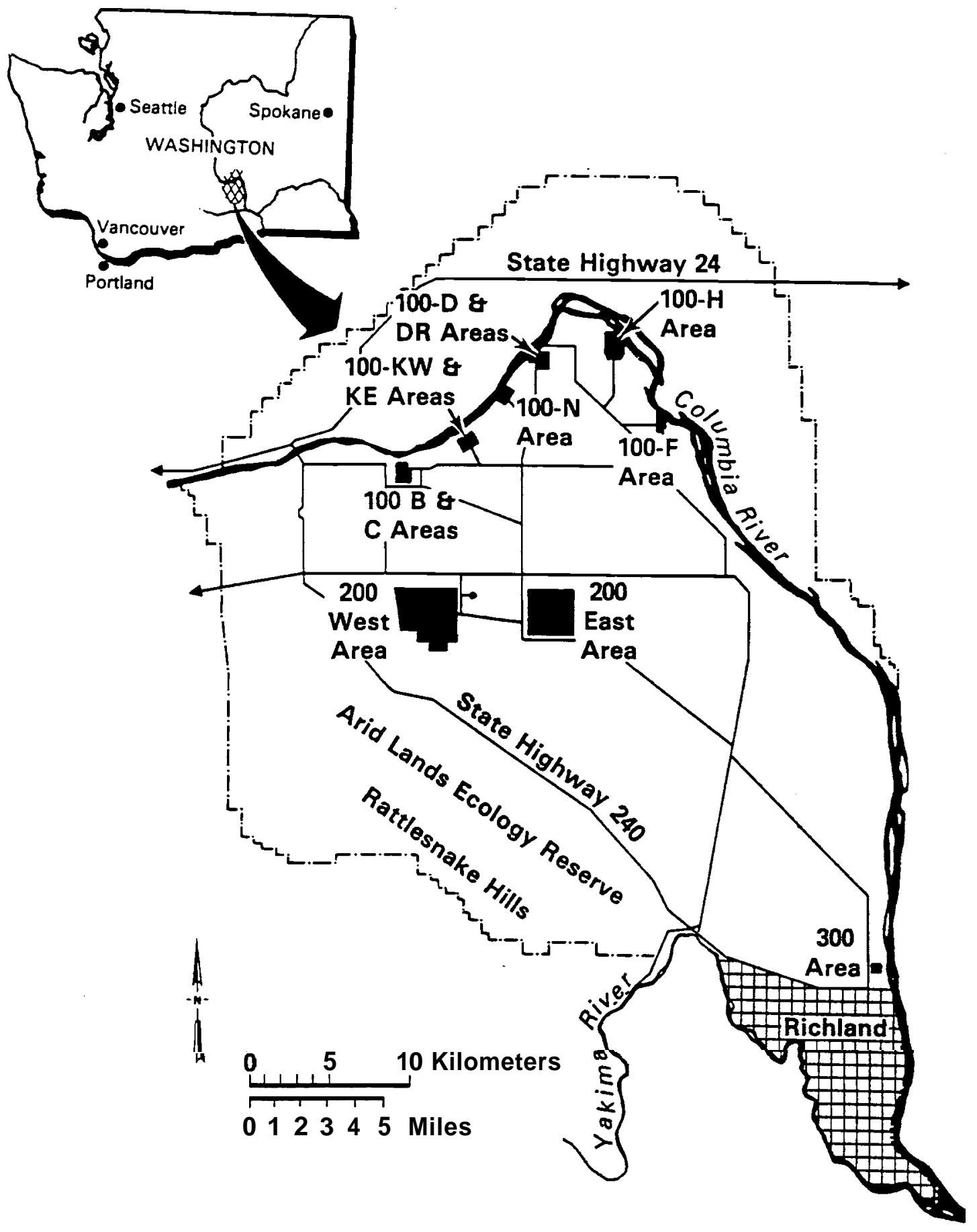

FIGURE 1.1. Hanford Site 


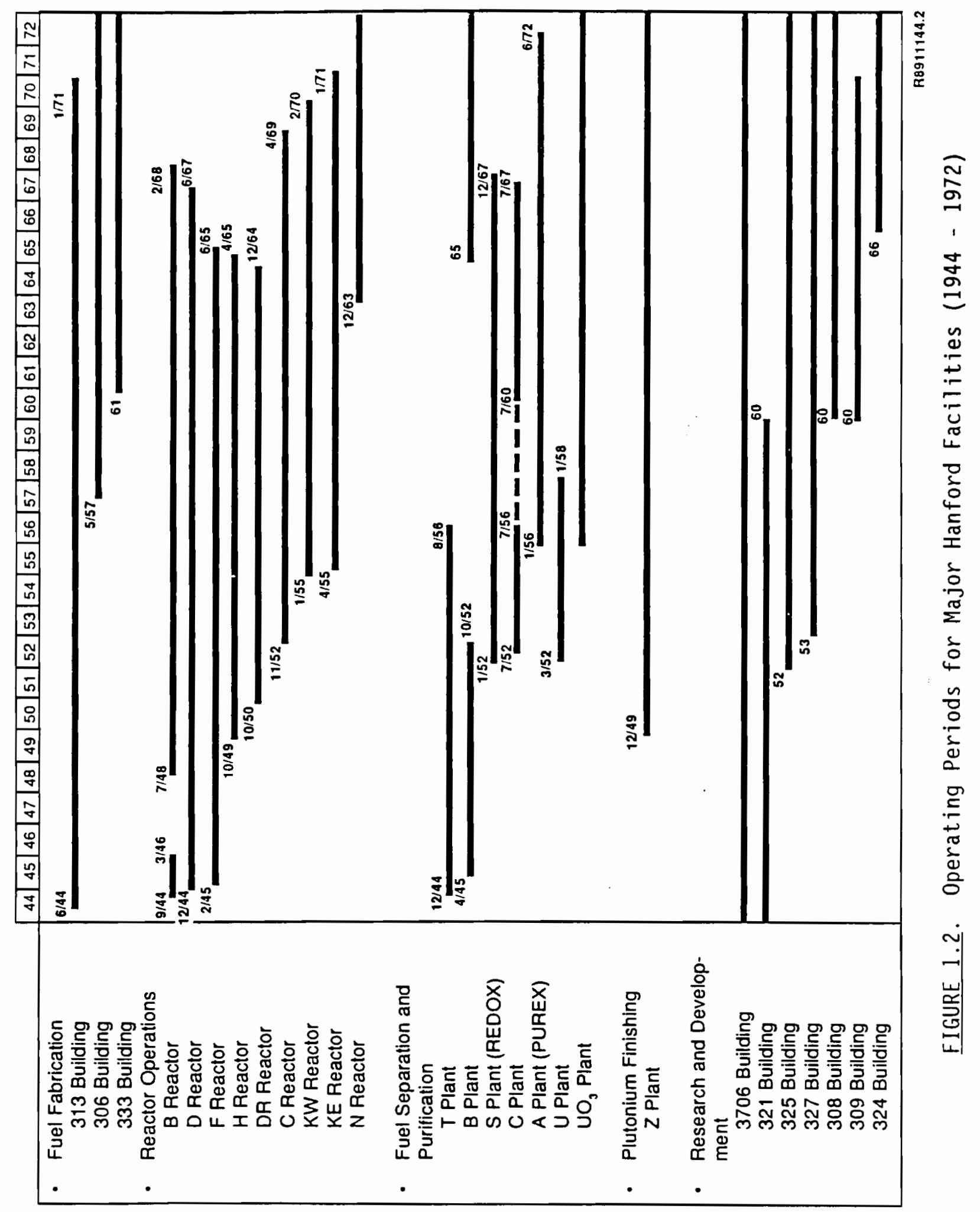


the Panel were selected by the deans of research of four Northwest universities. Other Panel members were appointed by the governors of Washington and Oregon, Native American tribes, and the public.

HEDR Project work is divided among several technical tasks. One of these tasks, Source Terms, is designed to develop quantitative estimates of al1 significant emissions of radionuclides by Hanford Site operations since 1944. The first step in this task is to describe the processes and facilities in which radioactive material was generated or used, and track the changes in these facilities throughout the study period. The study period for Phase I of the HEDR Project focuses on 1944 through 1947 for emissions to air, and 1964 through 1966 for liquid emissions. Processes and facilities are described here in sufficient detail to give the reader a general understanding of the basic operations and the size and layout of buildings in which the processes occurred. A timetable for each of the major facilities shows periods of operation and major events that may have affected the release of radionuclides to the environment. The major effluent streams from these facilities are described.

This report does not quantify the release of radionuclides from these operations. Quantities of radioactive materials released by Hanford Site operations will be addressed in separate reports.

The work described in this report was conducted in accordance with the requirements of ANSI/ASME NQA-1 1986 Edition, Quality Assurance Program Requirements for Nuclear Facilities, as interpreted by PNL's Quality Assurance (QA) program.

All staff performing work described here are adequately trained and qualified. All procedures used to support this report were appropriately written and controlled in accordance with PNL QA program requirements. Records that support the data in this report were created and stored in accordance with applicable HEDR record control requirements.

Drafts of this document underwent internal independent technical review. Review comments were satisfactorily resolved with no controversial resolutions to the comments. 
The material in this report is presented sequentially relative to the Hanford Site operations. Chapter 2.0 describes fuel manufacturing, Chapter 3.0 contains information on the reactor operations--from irradiation of the fuel to spent fuel storage, and Chapter 4.0 is an account of separations processes--from dissolving the spent fuel to final storage. Uranium recovery is also included in this chapter because uranium was recovered in the REDOX and PUREX Plants as part of the separations process. Chapter 5.0 is a description of the plutonium finishing operations. Major research and development activities are discussed in Chapter 6.0. Although procedures and equipment for handling radioactive waste are covered in each chapter for the facilities described, the tank farm and processes to recover specific radioisotopes from the tanks are described in Chapter 7.0. Chapters 8.0 and 9.0 contain references and a glossary, respectively. 


\subsection{FUEL FABRICATION}

Uranium metal fuel for the Hanford Site nuclear reactors was fabricated in the 300 Area, which is located 4 miles north of Richland, Washington (see Figure 1.1). The first fuel produced was aluminum canned fuel, which was used in all the reactors except $N$ Reactor, which used zirconium-clad fuel.

At the startup of fuel fabrication operations at the Hanford Site, uranium billets were brought into the fabrication plants, shaped, and sized into slugs. Later, the slugs were made elsewhere and shipped to Hanford. The first two sections in this chapter describe the original processes and facilities for both the aluminum- and zirconium-clad fuel. Section 2.3 gives a timetable of operations and describes major changes in the process after startup. Section 2.4 describes effluent systems associated with fuel fabrication. Information on aluminum-clad fuel was obtained primarily from Parker (1947). Timetable events were found in DeNeal (1965).

\subsection{PROCESS DESCRIPTION}

In the Hanford Site nuclear reactors, uranium fuel elements are in intimate contact with water, which carries away the heat generated by fission. Because uranium is highly reactive with water, the slugs must be sealed to prevent direct contact of the uranium metal with water. The slug jacket or covering must have low neutron absorption capacity so that neutrons needed to self-sustain the nuclear reaction are not lost to the jacket, and a high heat transfer capability for heat exchange from the fuel to the water. Aluminum in the form of a thin metal can was chosen as the jacket material for the fuel elements for all the reactors, except $\mathrm{N}$ Reactor, which used zirconium.

The fuel canning process was stringent, both in the quality of the uranium and in the fit and seal of the can. Fuel reactivity could be reduced by low density (voids) in the slugs, chemical impurities, and fractional differences in the slug diameters. Void space in the fuel elements also led to fuel ruptures in the reactor. Heat transfer through the jacket required a uniform heat-conducting bond between the uranium and the surrounding aluminum 
or zirconium and a gas-tight closure. A perfect seal was required to prevent contact of the uranium metal fuel and water. The following section describes the process steps for preparing and using aluminum-clad fuel. Zirconium-clad fuel is discussed in Section 2.1.2.

\subsubsection{Aluminum-Clad Fuel}

Uranium was brought into the fabrication plant as billets or bars of metal. The billets were preheated in a furnace to a temperature corresponding roughly to a red heat and shaped into long rods in an extrusion press. Extruded rods were put into an outgassing chamber and heated in an atmosphere of argon to drive off occluded gases. Slightly bent extruded rods were pounded straight.

A turret lathe roughly cut the rods into shorter lengths called slugs. The slugs were given a finished cut in another turret lathe. Finished slugs were inspected, then degreased by immersion in a nitric acid solution.

Cleaned slugs were canned by dipping the slugs in a succession of molten baths and pushing them into an aluminum can. An aluminum cap was then pushed into each can, the end of the cap was machined down to a definite overall length, and the top edge of the cap was welded to the can.

The finished slug was tested for perfect seating, bonding, and welding. The seating test was made by viewing an X-ray of the slug. Leak testing of the fuel element was done in an autoclave under steam pressure.

A11 scrap and waste uranium in the process was salvaged. The chips and turnings from the machining operations were sorted, broken into smaller pieces, washed, dried, and pressed into briquettes. The tailings from all washes and quenches were allowed to settle, and the decanted 1iquid was filtered. The settlings and all collections of dust were put in an oxide burner where the small particles of uranium metal were burned to oxide in a gas furnace. This uranium oxide was then put in 5-gallon buckets and shipped off the Hanford Site.

The method just described was known as the triple-dip process. The lead-dip process, a simpler canning scheme, replaced the triple-dip process as the standard fuel element fabrication process in March 1954. The lead-dip 
process had two principal advantages over the triple-dip process: 1) canning costs were lower because fewer operations and less equipment were required, and 2) the structure and properties of the uranium metal were essentially unchanged in the canning process, thus the uranium metal retained its desirable properties obtained during fabrication and heat treatment of the uranium.

\subsubsection{Zirconium-Clad Fuel}

The fuel for $N$ Reactor was a tube-in-tube design consisting of a metal1 ic uranium core surrounded by a thin zircaloy-2 cladding (Figure 2.1). The inner fuel tube was enriched to $0.95 \%$ uranium-235 $\left({ }^{235} \mathrm{U}\right)$. The outer fuel tube was enriched to either $0.95 \%$ or $1.25 \%{ }^{235} \mathrm{U}$. The following sequence of operations was performed to produce these fuel elements:

1. Component cleaning - Uranium billets, zircaloy-2 cladding she $17 \mathrm{~s}$, and copper-silicon components were subjected to cleaning operations that included vapor degreasing in perchloroethylene, acid etching and cleaning, process and deionized water rinses, and warm-air drying.

2. Billet assembly and preheating - The uranium core and components were assembled into billets immediately after cleaning to prevent oxidation. The inner zircaloy-2 shell was placed inside the uranium core, the outer shell outside the core, and the coppersilicon jacket outside the outer shell. End plates were fusion welded, helium-leak tested, and sealed. Billet assemblies were preheated in hot-air electric furnaces capable of reaching $1450^{\circ} \mathrm{F}$ temperatures.

3. Extrusion - Preheated billet assemblies were extruded to the tubular fuel configuration in a high-pressure press. The coppersilicon jacket surrounding the uranium billet and zircaloy-2 cladding prevented oxidation of metallic surfaces during heating and acted as a lubricant during extrusion.

4. Element shaping and cleaning - Extruded fuel tubes were cut into fuel element lengths by saws. The sawing was done under water to prevent burning of the small pyrophoric metal chips that were produced. Both ends of the fuel pieces were machined, then processed through hot nitric acid to remove the rest of the copper-silicon jacket. Pieces were then chemically milled in an acid bath and etched in another acid solution. 


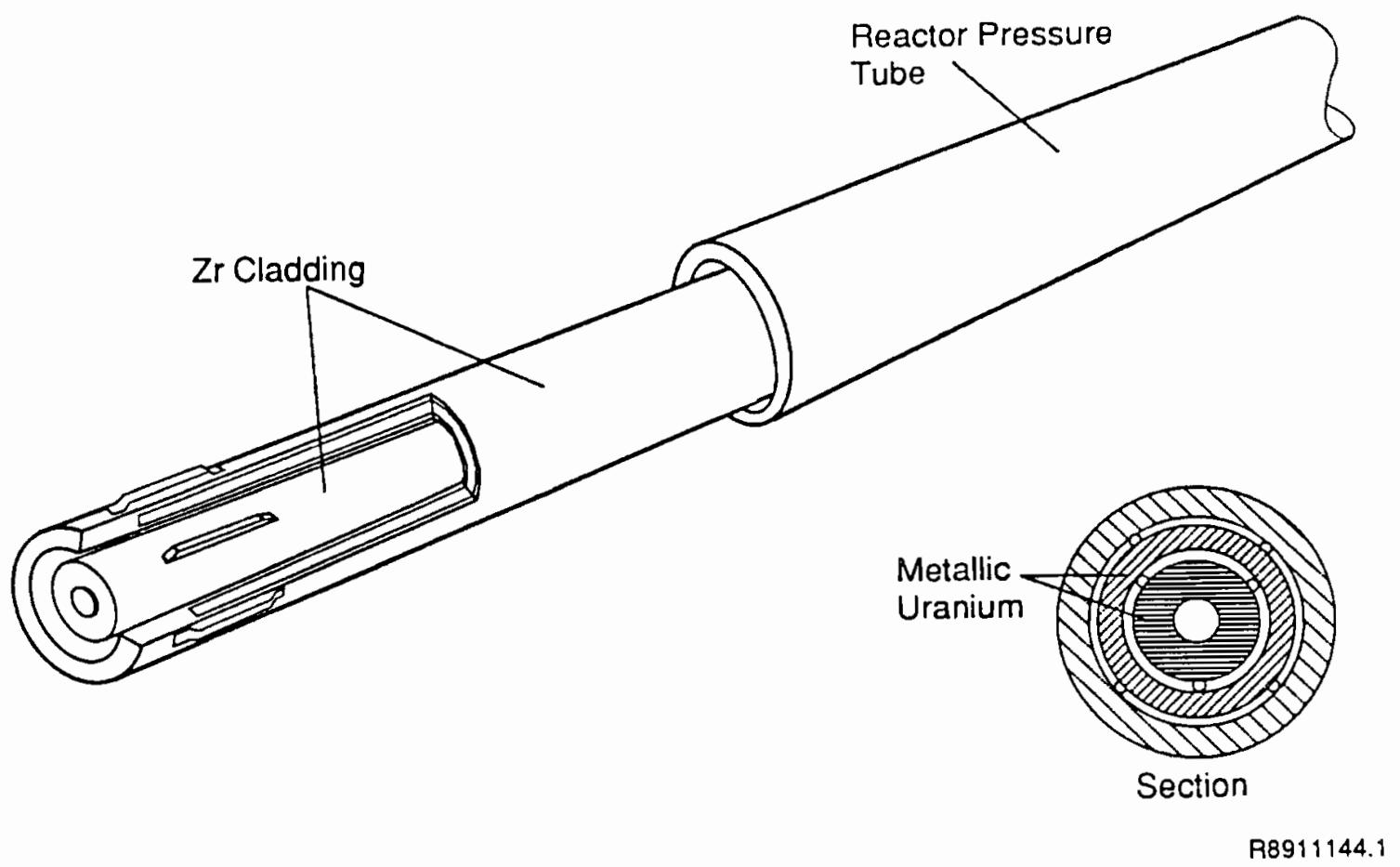

FIGURE 2.1. Zirconium-Clad Fuel Design

5. End cap - Zircaloy-2 end caps were used to seal the pieces, which were then heat treated in a high-temperature salt bath. The ends were machined, and the pieces were degreased, then cleaned with an abrasive blast. After welding the end cap, elements were tested and further cleaned.

\subsection{FACILITY DESCRIPTION}

This section describes the facilities in which fuel manufacturing took place. Aluminum-clad fuel was produced in the 313 Building in the 300 Area (see Figure 1.1) from 1944 to 1971. Zirconium-clad fuel production took place in the 333 Building, which operated from 1961 until 1988.

\subsubsection{Aluminum-Clad Fuel}

Reactor fuel was manufactured in the 300 Area, primarily in the 313 Building. Figure 2.2, based on 1964 operations, shows facility locations within the 300 Area. Operations in the 313 Building included inspection of incoming components, production of fuel elements as described in Section 2.1.1, and support operations. The original structure was a steel 


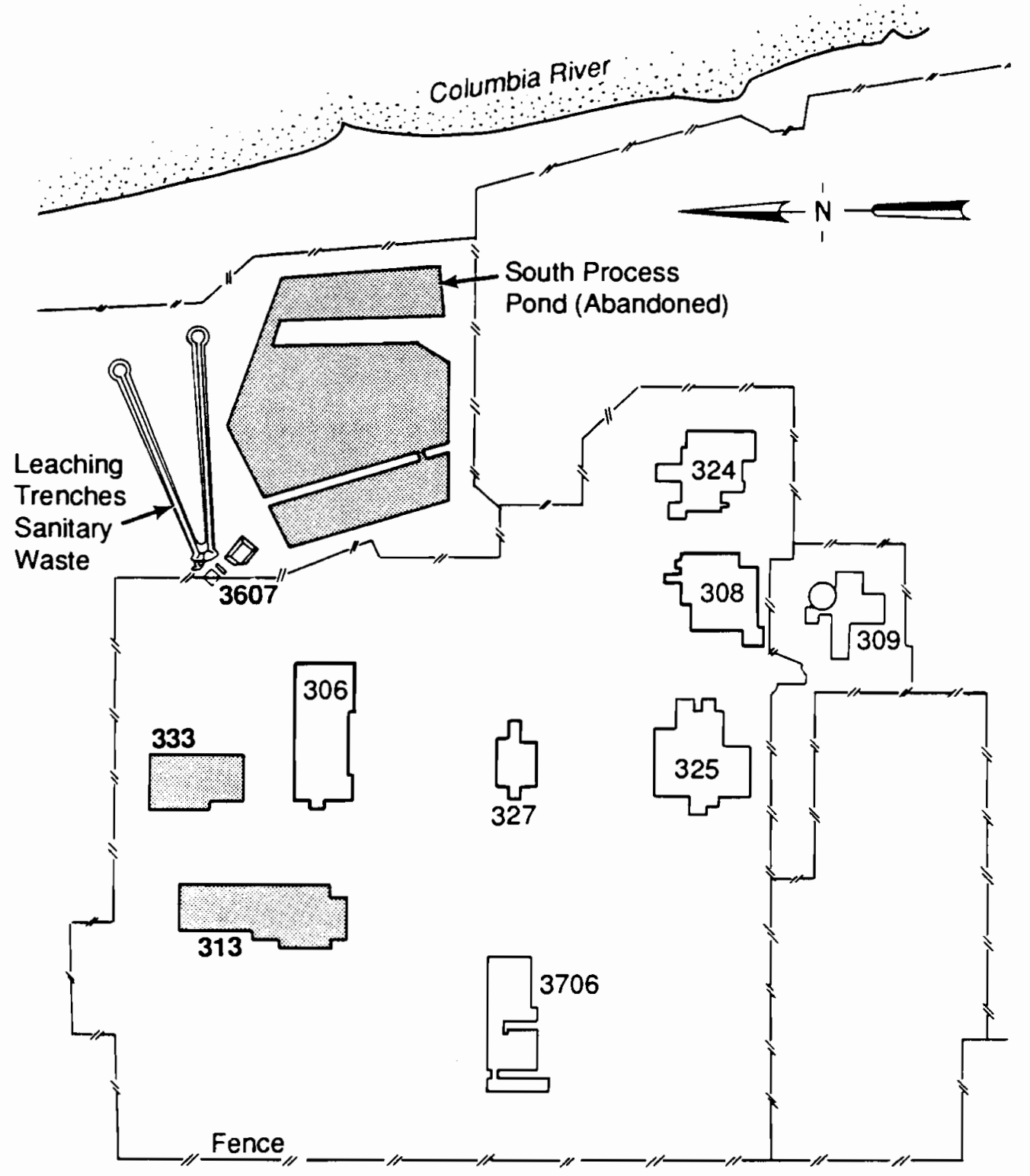

FIGURE 2.2. Fuel Manufacturing Facilities in the 300 Area

frame building with concrete block walls and a concrete foundation and roof. Exhaust fans provided ventilation. Built in two phases, the final structure had a total area of more than $76,000 \mathrm{ft}^{2}$.

The 306 Building (see Figure 2.2) began operations as a pilot plant for fuel manufacturing activities in May 1957. This facility housed a complete fuel element canning line including component preparation, canning, finishing, and all inspections except autoclaving. 
The 306 Building is two stories high with no basement. The framework is bolted steel, and the roof on the original building is metal deck. Exterior siding consists of fluted-steel insulated panels. Total area of the building after the second-phase addition is about $80,000 \mathrm{ft}^{2}$. The building was not designed for plutonium or fission product work, so air-pressure barriers and cleaning systems for radioactive contamination were not included; however, hoods and individual exhausts are used in the building as well as filters.

\subsubsection{Zirconium-Clad Fuel}

Production of $\mathrm{N}$ Reactor fuel took place in the 333 Building (see Figure 2.2). This building housed production operations as described in Section 2.1.2 as well as a small area devoted to manufacture of fuel supports. other support operations in the building were instrument, maintenance, and electrical shops and metallurgy and quality control laboratories. The structure is steel frame with metal-panel walls and a total floor area of about 49,000 $\mathrm{ft}^{2}$ (Geier 1966).

\subsection{TIMETABLE}

Major events affecting the fuel manufacturing process are shown in the following timetable. Timetable dates are from DeNeal (1965) unless otherwise noted.

5/44 Installed canning facilities in 313 Building.

6/44 Started making aluminum-clad fuel in 313 Building.

10/25/48 Liquid waste pond ruptured. After returning the pond to operating condition, another pond was dug, and both were used for liquid waste disposal.

1953 Transferred a11 uranium processing to new facilities at Fernald.

3/54 Converted triple-dip process to lead dip.

1955 Expanded production facilities to meet requirements of two new reactors (KE and $\mathrm{KW}$ ).

1961 Started making coextruded zirconium-clad fuel for $\mathbf{N}$ Reactor in 333 Building. 
1/71 Ceased production of aluminum-clad fuel.

1988 Placed zirconium-clad fuel production capability in 333 Building in standby mode.

\subsection{EFFLUENTS}

As mentioned in the fuel fabrication process description in Section 2.1, efforts were made to salvage all scrap and waste uranium in the process. Rudimentary in the early years, these salvaging efforts developed over time. By 1947, scrap from machining operations, tailings from washes and quenches, and collections of dust were burned to uranium oxide in a gas furnace and packaged in 5-gallon buckets.

No attempt was made to confine particles and gases emitted from the fuel fabrication operations in the early years. In comparison with other radionuclides on the Hanford Site, the radioactivity of natural uranium was considered relatively minor. Consequently, there was as much emphasis placed on protection of personnel from chemical hazards as from the radiation hazards from natural uranium.

Liquid effluents from the fuel fabrication plant were discharged to the process sewer, which flowed into two ponds. The liquid seeped through the pond bottoms into the ground water and the adjacent Columbia River. These effluents included large quantities of process chemicals such as sodium nitrite, sodium nitrate, nitric acid, sodium hydroxide, sodium aluminate, copper nitrate trichloroethylene, and uranium. Smaller amounts of sodium dichromate, sodium fluoride, silver salts from photographic processes and other trace chemicals from 300 Area programs were also present. The 300 Area Process Ponds, as well as all other inactive Hanford liquid and solid waste disposal sites, are described in a three-volume document by Stenner et al. (1988). 


\subsection{REACTOR OPERATIONS}

Nuclear reactors at the Hanford Site were composed of stacked graphite blocks, called piles, through which fuel rods and control rods were inserted. This chapter describes the process by which uranium was converted to plutonium in the reactors. The nuclear reactions are described, as are the supporting functions of moderating and cooling the reactors. Also described are support facilities, a timetable of major operations, and changes to the reactor operations after startup that affected the effluent streams. Most of the descriptive information in this chapter comes from Parker (1947).

\subsection{PILE REACTIONS AND SUPPORT SYSTEMS}

The purpose of the Hanford Site reactors was to produce a new element, plutonium, from two isotopes of uranium via nuclear reaction. These uranium isotopes have atomic weights of 235 and 238 and occur naturally in the ratio of 1 part to 139 parts, respectively. The $238 \mathrm{U}$ isotope produces the plutonium, while the $235 \mathrm{U}$ isotope sustains the reaction by producing neutrons during nuclear fission.

Both of the fundamental reactions of the process involve the capture of neutrons. The reaction with $238 \mathrm{U}$ is as follows:

$$
238 U+\text { neutron } \rightarrow 239 U+\text { gamma ray }
$$

$239 \mathrm{U}$ is unstable and decays radioactively by emitting a beta ray. This decay proceeds with a half-1ife of 23 minutes and may be written

$$
239 U \rightarrow 239^{N p}+\beta
$$

The new element formed is called neptunium and is also unstable, decaying by another beta emission with a half-life of 2.3 days as

$$
{ }^{239} \mathrm{~Np} \rightarrow{ }^{239} \mathrm{Pu}+\beta
$$

The plutonium formed from this reaction has a half- 1 ife of 24,000 years. 
The reaction of a neutron with the $235 \mathrm{U}$ isotope results in a fission or splitting apart of the nucleus. This fission results in the production of an average of 2.2 neutrons for each one captured, and thus supplies a source of neutrons to sustain both reactions. The fission reaction is

$$
235 U+\text { neutron } \rightarrow A+B+2.2 \text { fast neutrons + energy }
$$

where $A$ and $B$ are nuclei of two elements of lower atomic number. The energy released per fission is about 200 million electron volts (MEV). The average energy of each neutron produced is 2 MEV.

These neutron reactions are initiated more effectively if the neutrons are of certain definite energies at a level approximating the energy of normal thermal agitation, or about 0.025 electron volts. Neutrons at this energy level are called thermal neutrons. Because the neutrons produced by fission of $235 \mathrm{U}$ are of very high energies (averaging 2 MEV each), called fast neutrons, it is necessary to reduce their energies to the thermal level so that a larger number of reactions can occur.

Fast neutrons can lose enough energy to be at the thermal energy range by causing them to pass through a medium that has a low atomic weight and a low probability of reaction with the neutrons. Carbon, in the form of graphite, was chosen as the moderator for the Hanford Site reactors.

Enormous quantities of heat are released in the graphite pile by the nuclear reactions. In the Hanford Site reactors, this heat was removed by cold water circulated at a high velocity in process tubes containing the fue 1 elements. Water was selected as the cooling medium because 1) it was available in large quantities and at low cost from the Columbia River, 2) relatively low pressure drops were required for flow at high rates, 3 ) it has a high heat transfer coefficient, and 4) it had been frequently used in heat exchangers.

To prevent water from reacting with graphite and uranium, the fuel was canned in aluminum jackets and set on ribbed aluminum process tubes in the reactor. The aluminum process tubes separated the water from both the graphite and the uranium (Figure 3.1). Because water is an effective absorber of 


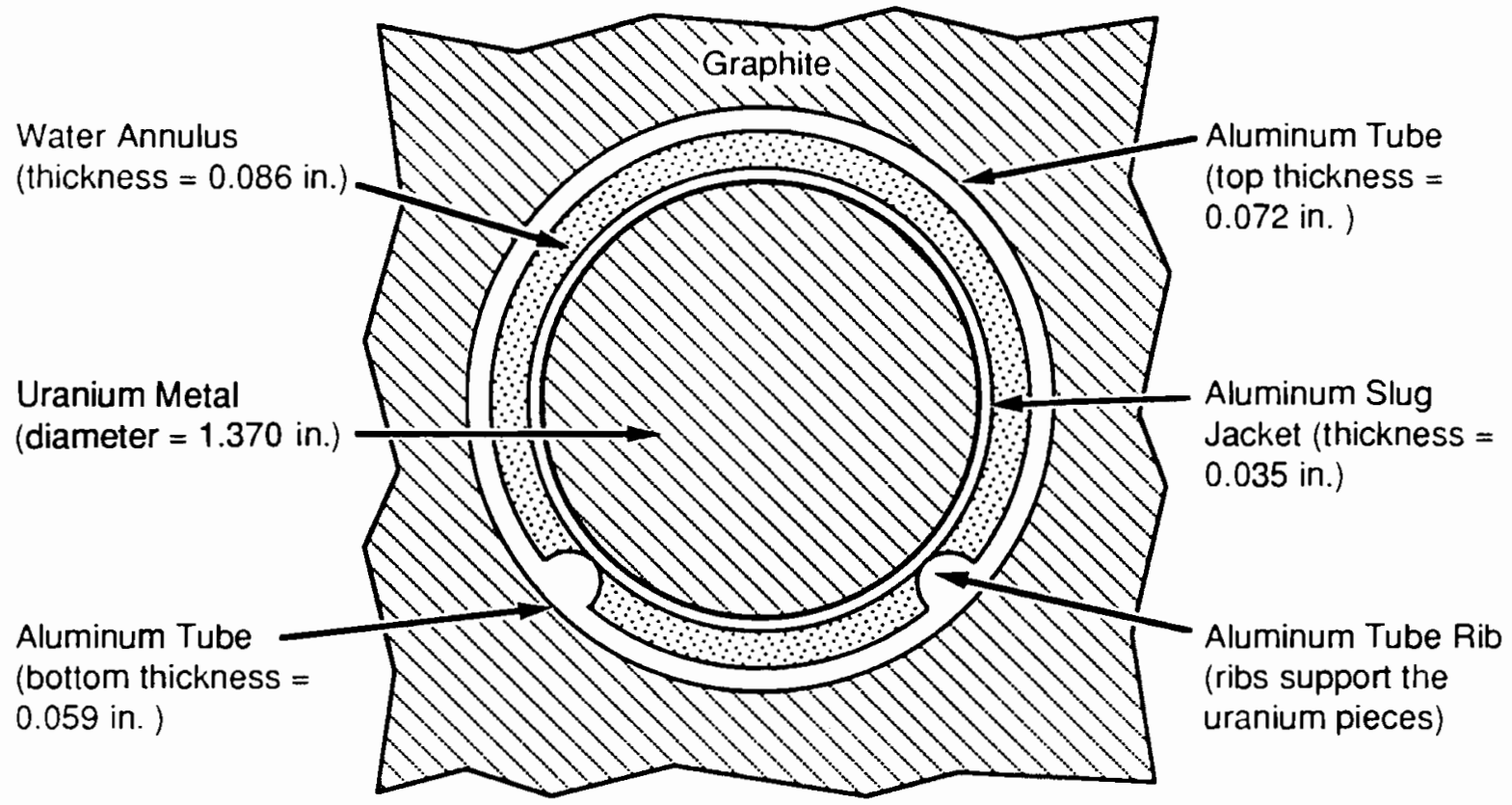

FIGURE 3.1. Cross Section of a Uranium Column in a Pile

neutrons, the amount of water in the graphite pile at any one time had to be kept at a minimum. The quantity of water that flowed through the relatively small annulus was sufficient to carry off the heat produced, but did not absorb enough neutrons to stop the chain reaction.

\subsection{FACILITY DESCRIPTION}

Nine plutonium production reactors were operated at Hanford; eight were similar in design. The first eight are described here; $N$ Reactor is discussed in Section 3.3. The pile design, pile control systems, cooling water system, and inert gas systems are described. A timetable is given of major changes in the processes and facilities during the study period, and the effluent streams produced during these years are discussed.

\subsubsection{Pile Design}

As pointed out in Section 3.1, an average of 2.2 neutrons is produced in a $235 \mathrm{U}$ fission. One of these neutrons was needed to fission another $235 \mathrm{U}$ atom to sustain the reaction. This allows 1.2 neutrons from each fission to be used in the production of plutonium. So that there will always be one 
neutron available for a new fission, it is necessary to adjust conditions to conserve the supply available. Neutrons can be lost to the cooling water, moderator (graphite), or other parts of the reactor system. The reactor piles were designed to minimize this loss and enhance as much as possible the neutron flux in the reactor and hence the plutonium production.

The graphite piles for the first eight reactors had graphite structures $36 \mathrm{ft}$ high by $36 \mathrm{ft}$ wide by $28 \mathrm{ft}$ 10ng. They were built of graphite blocks 4-3/16 in. wide by 4-3/16 in. high by 48 in. long, set with alternate 1 ayers crisscrossed to give better stability. Alternate rows in the lengthwise layers were pierced with holes in the form of cylindrical channels. These channels were 8-3/8 in. apart and were lined with ribbed aluminum tubes that were charged with the aluminum-clad uranium metal fuel elements during operations. Six of the reactor piles held 2004 fuel tubes; KE and KW reactors were larger and held 3220 tubes; Figure 3.2 shows the approximate layout of a graphite pile.

An additiona1, 2-ft-thick layer of graphite was added to each side of the pile so that leakage of neutrons through the sides of the pile would be minimized. The extra graphite contained no uranium and therefore acted as a reflector, sending most of the leakage neutrons back into the graphite that contained the uranium. In addition to the extra graphite, a cast-iron shield 10.5 in. thick provided a thermal shield, absorbing about $99.5 \%$ of the total energy escaping the reflector. A biological shield consisting of $4 \mathrm{ft}$ of alternating layers of steel and masonite were added to the thermal shield to further reduce radiation escaping from the reactor.

The fuel tubes running through the graphite extended outward through the thermal and biological shields, providing a simple means for charging the fuel elements into the pile and discharging the irradiated plutonium-bearing fuel elements out of the pile. To shield against the radiation coming out of the ends of these tubes, dummy fuel elements made of steel, lead, and aluminum were placed in both ends of the tubes.

The procedure for charging and discharging fuel tubes was simple. The pile was shut down by inserting the control rods and the water supply was reduced but still had a flow capable of carrying off the radioactive heat of 


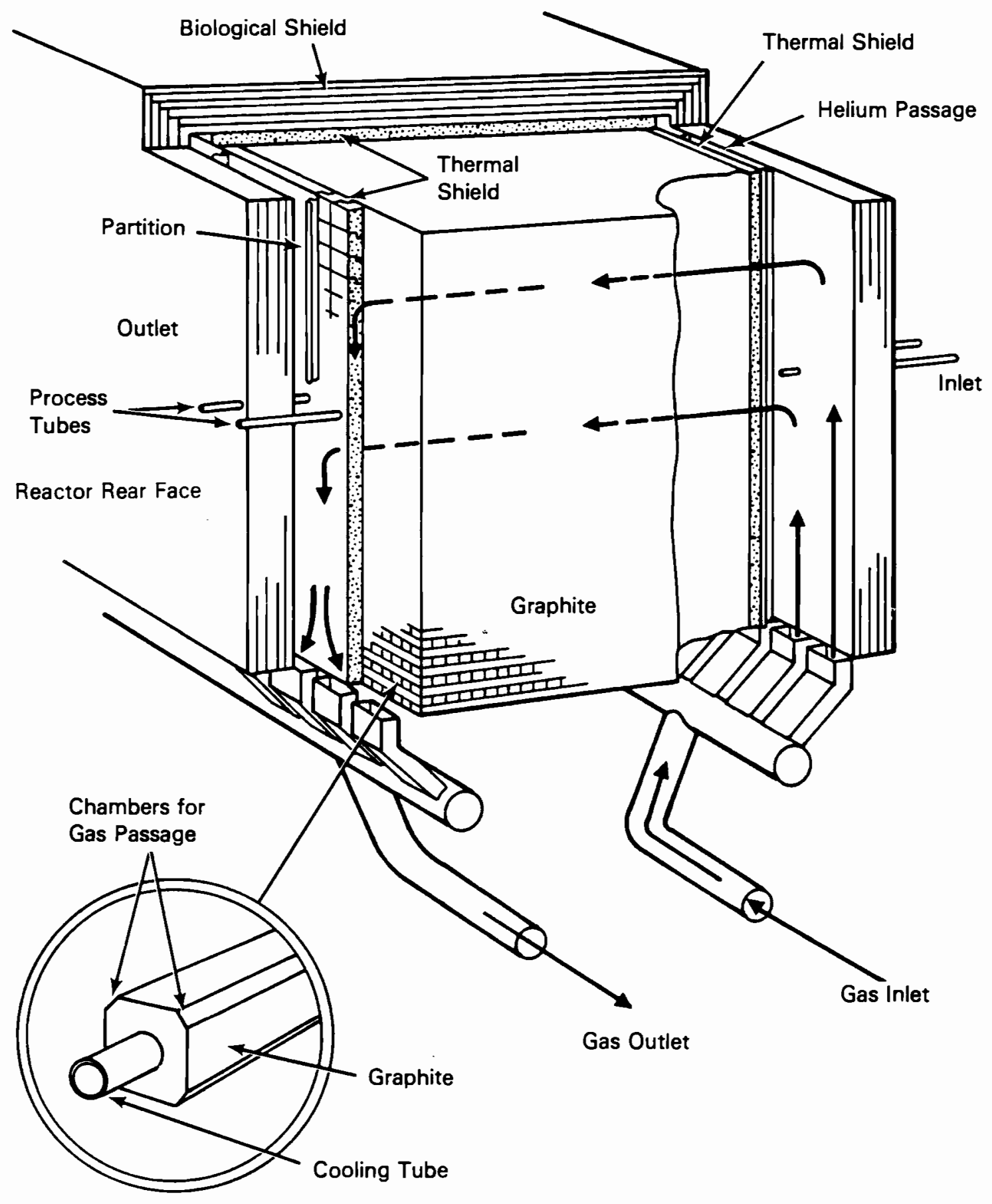

FIGURE 3.2. Reactor Shields and Inert Gas Atmosphere (Lockwood 1958) 
the fuel elements. The end caps were removed from the front and rear face ends of the tubes to be charged, and a charging machine was coupled to the front face end of the tube. The charge of fuel elements was placed in the charging machine one at a time, starting with the rear-face dummy charge, following with the fuel charge, and finishing with the front-face dummy charge. As the new fuel elements were pushed in, the old ones fell out of the rear end of the tube into a basin of water. When the end caps were replaced, the pile was restarted. The irradiated fuel elements removed from the pile were kept under $20 \mathrm{ft}$ of water to shield personnel from radiation exposure. Using long tongs to handle the fuel elements from above, workers picked up the fuel elements, sorted them, and placed them in buckets at the bottom of the basin.

\subsubsection{Pile Controls}

Three types of rods were used in the Hanford piles to control nuclear reactions: regulating rods, shim rods, and vertical safety rods. The regulating rods contained boron and controlled the power output by pushing into or withdrawing from the pile. Boron is a neutron absorber, diverting neutrons from the fissioning and plutonium production processes, thus slowing the rate of nuclear reactions. Each regulating rod was about $75 \mathrm{ft}$ long: half was the neutron-absorbing portion and the other half was a mechanical linkage between the section entering the pile and the drive and water supply. Water was forced through the rods at $10 \mathrm{gal} / \mathrm{min}$ to carry away heat generated in the rod. An outer aluminum casting gave rigidity to the structure.

Figure 3.3 shows a cross section of a control rod and hole. Regulating rods were used to control the minute-to-minute power output of the pile.

Shim rods were similar to regulating rods but were used to start and stop pile reaction under normal operations, to provide more minute-to-minute regulation of power if needed, and to act as safety rods, stopping the pile reaction in an emergency.

Vertical safety rods were provided primarily to shut down the pile in case of emergency. Twenty-nine safety rods were placed above the pile where they could be dropped into the pile in 2.0 to 2.5 seconds after an 


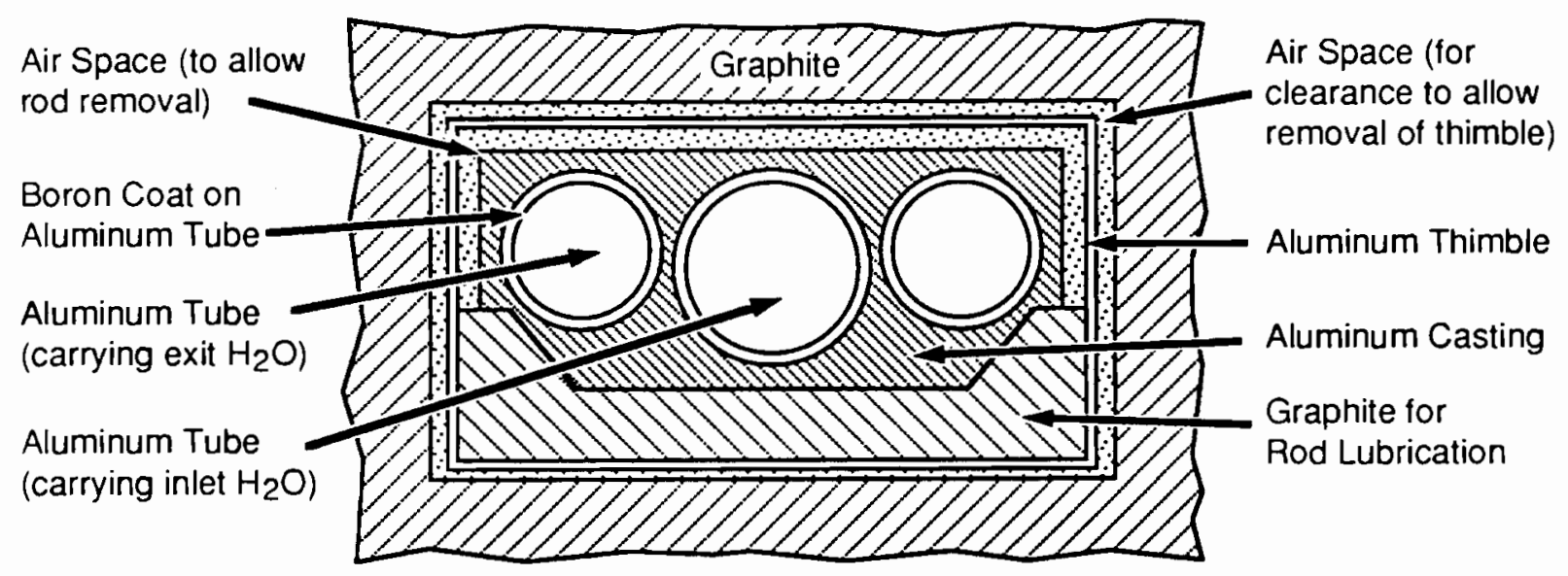

FIGURE 3.3. Cross Section of Control Rod and Hole

emergency signal was given. These rods were steel tubes 2.25 in. diameter and $35 \mathrm{ft}$ long containing $1.5 \%$ boron.

In addition to the three types of rod control, one other control was provided. On the chance that the pile might shift its position or that other events might take place to prevent the desired number of safety rods from entering the pile at the time of impending water failure, a device was set up for forcing 1.0 to $1.5 \%$ borax solution into the safety wells originally provided for the 29 safety rods. The aluminum liners for these wells were called "thimbles." In 1952 the thimbles were removed and this system was replaced by small, boron-filled balls that dropped into the same vertical channels as the vertical safety rods.

\subsubsection{Cooling Water System}

In the once-through cooling system of the first eight reactors, water was taken out of the Columbia River, treated to prevent fouling and corrosion of the pile's process tubes and enhance heat transfer, sent through the reactors, held in a retention basin, then spilled back into the river. A secondary function of the treatment facilities was to remove impurities from the river water, thus reducing the chance of these impurities becoming radioactive through neutron activation in the reactor. To provide redundant water systems to make available a continuous supply of water for emergencies, a 
network of interconnecting lines, various by-passes, and special standby pumping facilities were provided at each reactor.

Water was pumped from the river with $10,000 \mathrm{gal} / \mathrm{min}$ motor-driven pumps into a 15-million-gallon reservoir that overflowed into another 10-milliongallon reservoir. From this reservoir water was pumped into each area's filter plant, which was designed for a capacity of about $38,000 \mathrm{gal} / \mathrm{min}$. The filtered water was then discharged into the clear wells, each of which had a capacity of 5 million gallons. From the clear wells, the water was directed into deaeration units that removed any dissolved gases in the water, including oxygen and carbon dioxide.

Treated process water was stored in pontoon-roofed, steel storage tanks, each with a capacity of 1.75 million gallons. From there water was pumped as needed through the pile. Under normal operation, the pressure of water entering the pile was maintained at $200 \mathrm{psi}$, which provided a total flow through the pile of about $30,000 \mathrm{gal} / \mathrm{min}$. In each individual fuel tube, the velocity averaged about $18 \mathrm{ft} / \mathrm{s}$.

Water leaving the pile contained radioactive activation products. A retention basin containing two reservoirs was used to hold up exit water for several hours to permit radioactive decay of the short-lived radionuclides before allowing the water to flow into the river. Figure 3.4 shows a schematic of the 100-D area water system.

\subsubsection{Helium System}

Helium was circulated through the pile to provide within it an atmosphere of high thermal conductivity and low neutron absorption. The high thermal conductivity helped maintain lower temperature differences between the many energy-absorbing parts of the pile, preventing overheating of various structural members and minimizing thermal expansion. The low neutron absorption of helium was necessary to reduce parasitic neutron loss in the pile, thus conserving neutrons for the reaction.

The helium system also acted as a monitor for detecting ruptured process tubes in the pile. The gas picked up moisture from leaks in the aluminum 


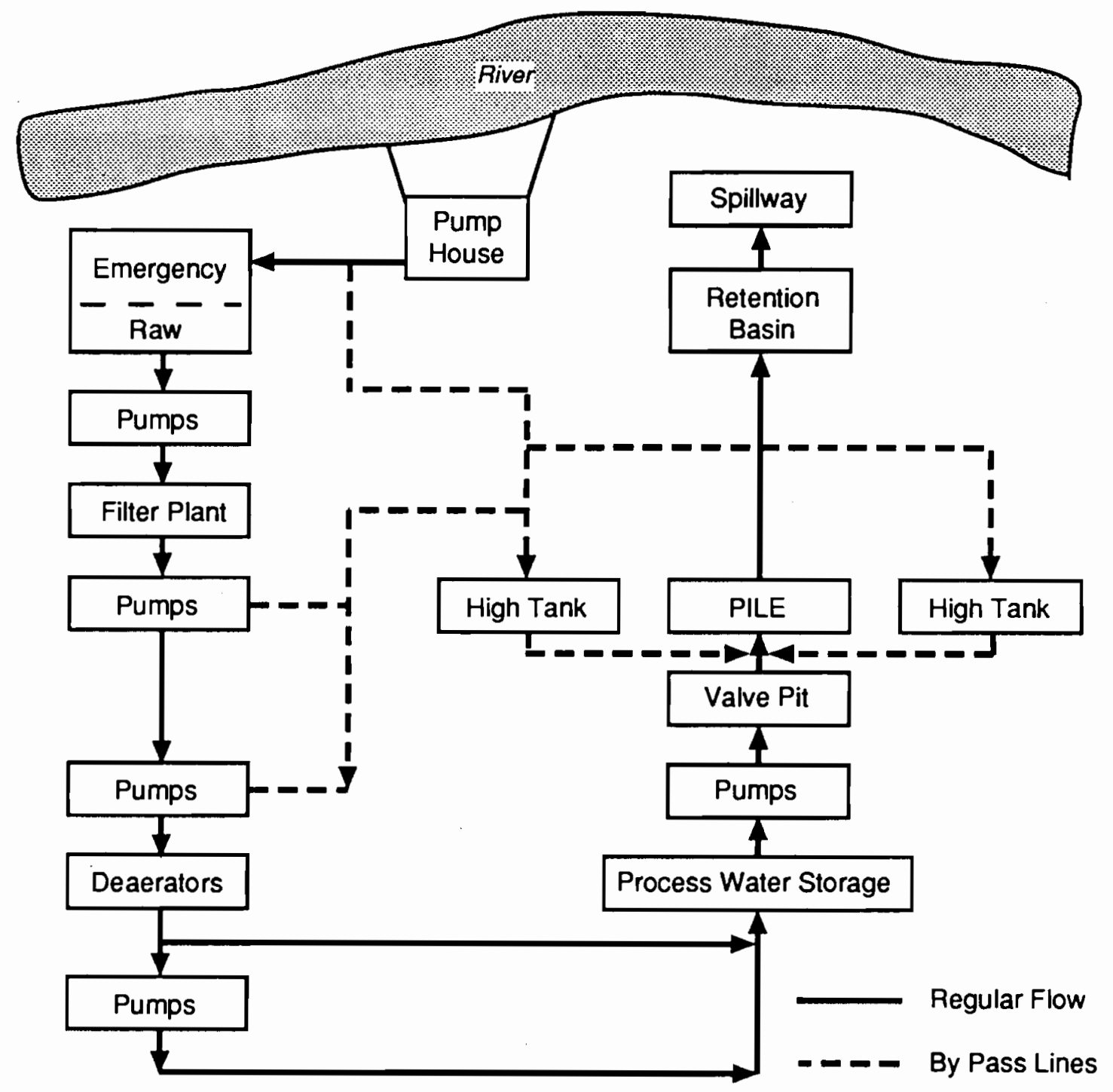

FIGURE 3.4. 100-D Area Water System

process tubes. The moisture content of the helium was monitored and recorded in the control room as it left the piles. Excess moisture signaled a tube rupture.

A purification system for helium was used to remove impurities that could become activated in the reactor. Before entering the pile, helium was purified to contain less than $0.01 \%$ argon, the element of primary concern. 
Helium was circulated through the pile at a rate of $2000 \mathrm{ft}^{3} / \mathrm{min}$. The gas entered the pile through a 2 -ft horizontal duct located about 15 feet below the thermal shield at the base of the pile (see Figure 3.2). This duct made a turn beneath the pile and discharged into the center of a perpendicular header located near and parallel to the charge face. The gas flowed upward from this header through slots into the space between the thermat and biological shields. The helium then worked its way through cracks between the thermal shield blocks and through channels provided by the graphite blocks. These channels were made at the corners of the graphite blocks that contained the process tubes as shown in the inset in Figure 3.2. The gas then discharged into a duct on the discharge side of the pile in a position comparable to the duct on the charge side.

The gas leaving and entering the pile was carried through underground pipes. After leaving the reactor, it was cooled, dried, and filtered before being recirculated through the pile. Helium was added to the system between the cooling and drying units. A flow diagram of the helium system is shown in Figure 3.5 .

In the early years of reactor operation (1944 to 1948), concern arose over expansion of graphite in the piles. Experiments were performed in 1947 using $\mathrm{CO}_{2}$ in the reactor atmosphere to reduce and slow down graphite expansion. The experiments were successful, and in 1948, $\mathrm{CO}_{2}$ was added to the reactor systems and gradually adjusted to optimal levels. The higher graphite temperatures resulting from the addition of $\mathrm{CO}_{2}$, and later from higher power levels, limited graphite expansion in the three original reactors ( $B$, $D$, and F) and enabled them to operate longer than their original design lives (DeNeal 1965).

\subsection{REACTOR DIFFERENCES}

Figure 3.6 shows the location of the reactor areas on the Hanford Site. $B, D$, and $F$ reactors were built in their own operating areas. Reactors $H$ and DR were built with the same design about 5 years later. DR was built near D. The C, KE, and KW Reactors used a slightly different design with larger fuel tubes on closer centers. C was built near B, and KE was built near KW. 


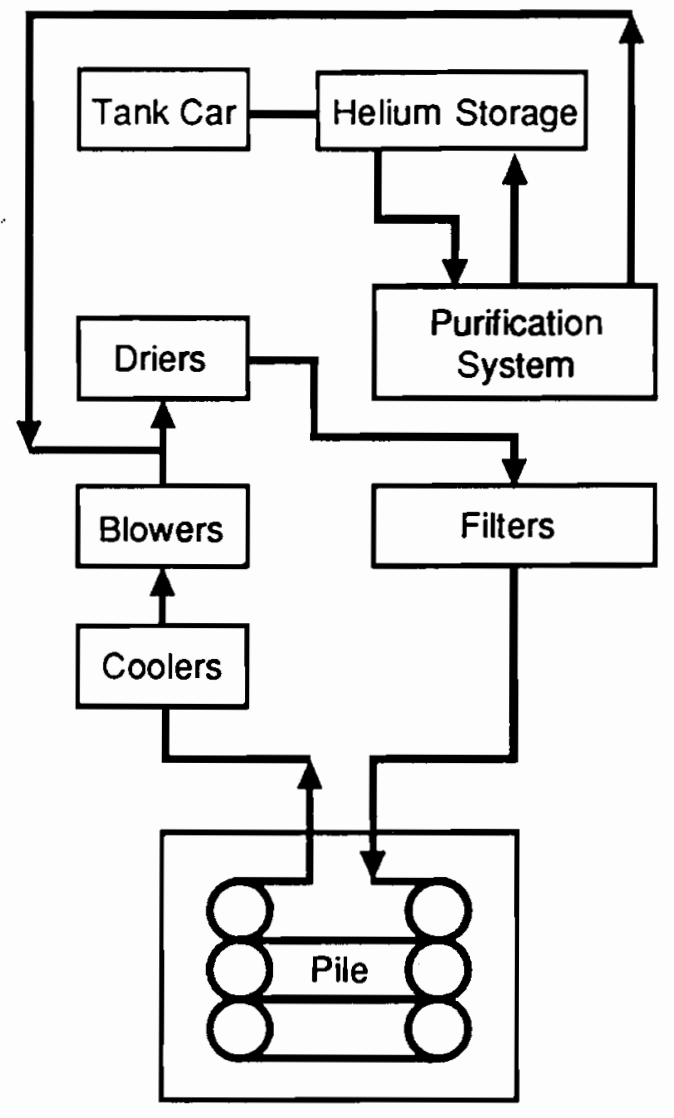

FIGURE 3.5. Flow Chart for Helium System

$N$ Reactor, which began operating in 1963, had a closed-loop cooling system, unlike the once-through cooling system of the other reactors. $\mathrm{N}$ Reactor was also a dual-purpose reactor, producing electrical power as well as plutonium. This general description of $\mathrm{N}$ Reactor was taken from United Nuclear Industries (1978):

The reactor is a graphite-moderated, pressure-tube, light-watercooled reactor designed and operated for economic and efficient production of special nuclear materials at up to $4000 \mathrm{MW}$ power. The reactor core is an 1800 -ton graphite cuboid 33 feet by 33 feet at the face and 39 feet long. A total of 1003 horizontal zircaloy-2 pressure tubes, designed for 1825 pounds of system pressure, penetrate the graphite moderator. The reactor coolant flows through the pressure tubes and transfers the heat from the approximately 366 metric tons of low enrichment uranium metal tubein-tube fuel elements to the boiling secondary coolant in the steam generators. Perpendicular to the pressure tubes are 34 horizontal 


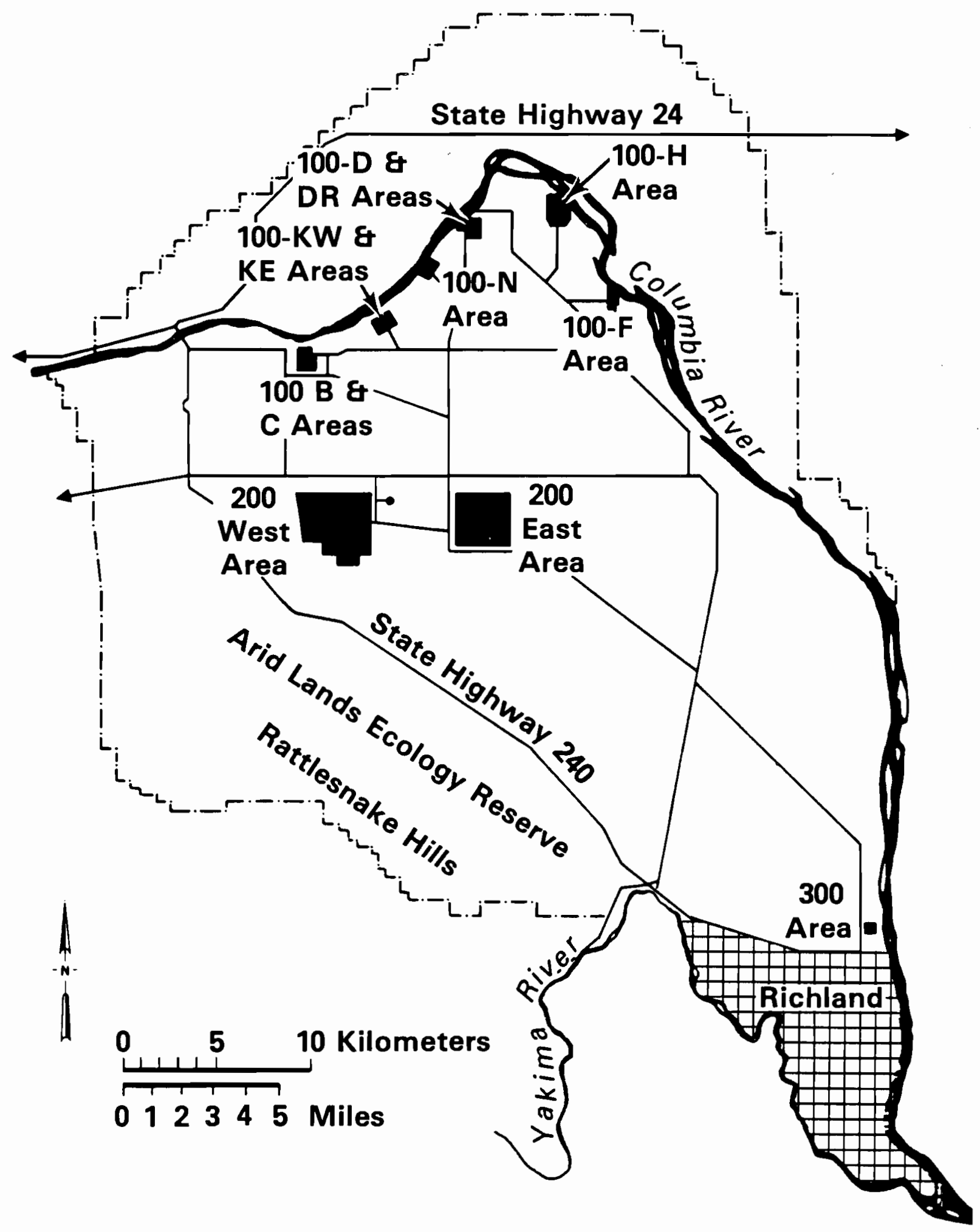

FIGURE 3.6. Location of Reactor Areas on the Hanford Site 
$\mathrm{B}_{4} \mathrm{C}$ containing control rods. The horizontal control rods enter the reactor from both sides and provide operating reactivity control, flux shaping and primary emergency shutdown control. A completely independent backup emergency shutdown control is provided by the ball safety system. A total of 107 vertical channels penetrating the core can be gravity filled with special neutron absorbing balls to assure rapid shutdown of the reactor.

\subsection{FUEL STORAGE}

Initially, spent fuel from the reactors was stored in the reactor buildings and in three identical buildings in the $200-\mathrm{N}$ area, just north of the 200 East Area. These buildings, designated 212-N, 212-P, and 212-R, contained storage basins and transfer facilities for moving buckets of irradiated fuel elements in and out of well cars.

Fuel elements were received from the 100 Area in buckets that held approximately 105 fuel elements, weighing about $8451 \mathrm{~b}$. These buckets were shielded in lead casks weighing about 17 tons, and two casks were carried by a well car to the 212 Buildings. The casks were covered with water in the well cars. Casks were vented with pipes through which water flowed, preventing the irradiated fuel elements from heating to a point where the jackets would be damaged.

At the 212 Buildings, the casks were lifted out of the well cars by cranes and lowered into transfer pits. As the cask was lowered, the cover was picked off when it contacted a ledge in the chute, and the cask was lowered farther into the water, then moved to the side so that a yoke from an overhead carrier could be lowered into the cask and engage the bucket handles. The yoke was then raised up to the level of the storage basin floor and moved by hand into the storage basin.

Irradiated fuel elements were stored in basins for about 40 to 60 days in the early years. Water flowed through the basin to prevent localized hot spots. Cooling time, or the time between discharge of an irradiated fuel element and its processing, was used primarily to reduce the radioactivity of gaseous fission products (primarily iodine) by allowing for radioactive decay of short-lived radionuclides before dissolution of the fuel in the fuel reprocessing plants. 
When the irradiated fuel was ready to proceed to the separation process, the procedure was reversed to get the buckets back into the well cars, which were then moved into the processing facility canyon.

Storage in these interim facilities was found to be an unnecessary operation, and after 1952, the buildings were no longer used to store irradiated fuel. Irradiated fuel elements were stored in the reactor basins for the specified cooling time, then transported by rail directly to the separations plants in cask cars.

\subsection{IIMETABLE}

The first three reactors, $B, D$, and $F$, were designed and built by the E. I. du Pont de Nemours Company, Inc. (du Pont), as part of the war effort. As shown by the timetable in Figure 3.7, these plants began operating in late 1944 and early 1945. General Electric took over the contract from du Pont for the Hanford Site operations in September 1946. The next five reactors were built from the late 1940s to the mid 1950s. N Reactor began operating in 1963.

Significant events occurring over the 1 ifetimes of the reactors and influencing the emissions of radionuclides to the environment are listed here and shown in Figure 3.7. Timetable dates are from DeNeal (1965) unless otherwise noted.

9/26/44 B Reactor startup

12/17/44 D Reactor startup

2/25/45 F Reactor startup

3/19/46 B Reactor shut down and held in standby status to conserve reactor life. Growth of reactor graphite was concern.

10/47 Nominal power level of $D$ and $F$ Reactor raised.

$1948 \mathrm{CO}_{2}$ added to reactor atmosphere to control graphite growth.

7/2/48 B Reactor restarted

5/30/48 First fuel element failure occurred. Total of two failures occurred in 1948. Fuel failures were detected by reactor effluent water monitoring instruments installed during construction for this purpose. 


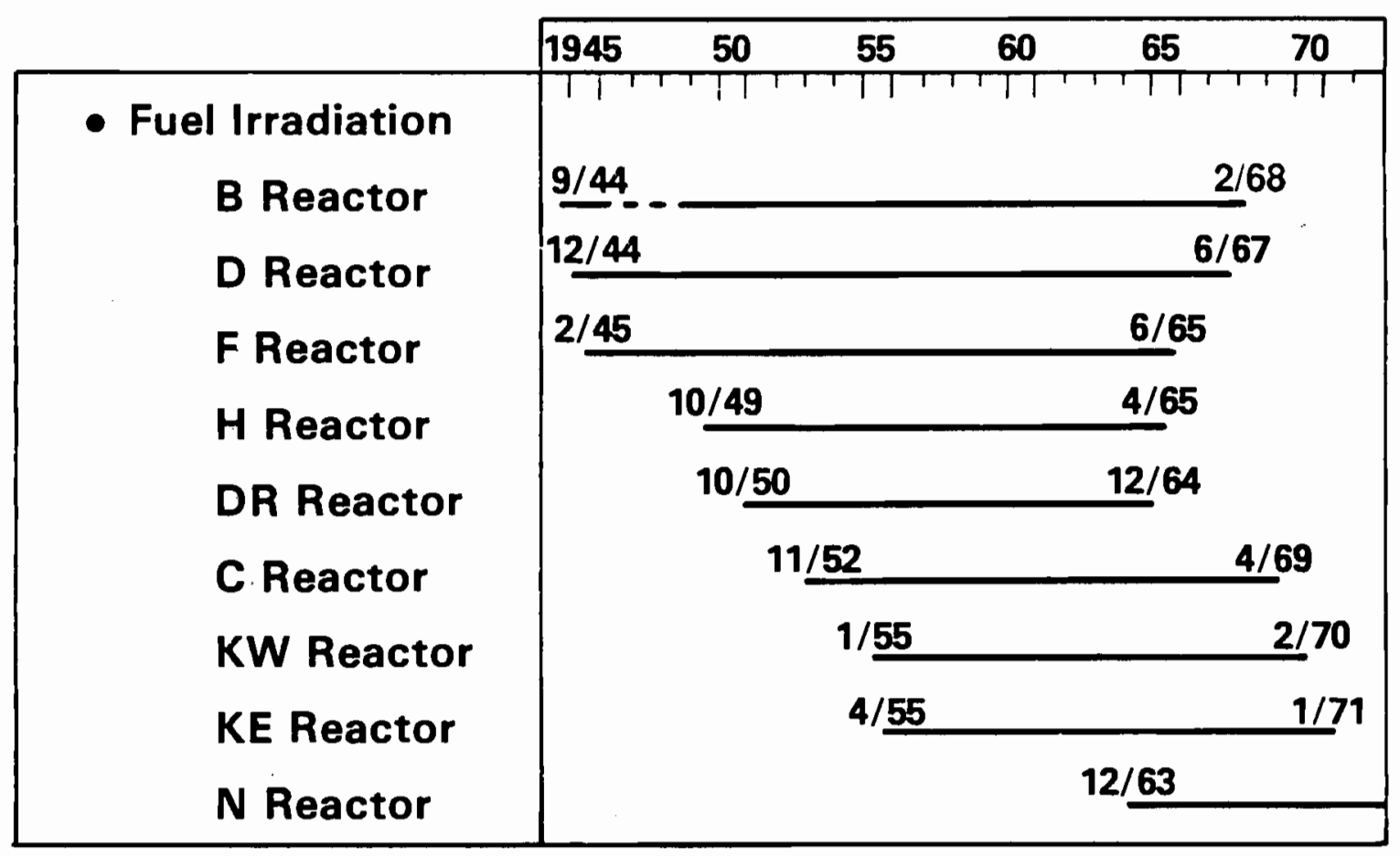

FIGURE 3.7. Operating Periods for Hanford Reactors

6/49 Nominal power level of D Reactor raised.

10/19/49 H Reactor startup

1950 Nominal power level of $F$ and $D$ Reactors raised. Nominal power levels of $B$ and $H$ Reactors raised several times.

6/10/50 Started irradiation of lithium-aluminum target elements for the production of tritium. Program completed during September 1951 .

10/3/50 DR Reactor startup

1951 More than 100 fuel element failures. From 1951 to 1964, the number of fuel element failures ranged from 242 in 1955 to 68 in 1963.

3/51 Raised discharge exposure of natural uranium from all reactors.

6/24/51 Discharged the lithium target elements for the production of tritium. Tritium separated at Building 108-B in specially designed facility (see Chapter 6.0). 
6/52 Shutdown 212N, P, and R fuel-storage facilities (Ruppert 1953)

11/52 Charged H Reactor with enriched uranium alloy.

11/16/52 Replaced borax solution safety control with boron-steel balls in $\mathrm{F}$ Reactor; balls were installed in other reactors in early 1953.

11/18/52 C Reactor startup

1/53 $C$ and $H$ Reactors charged with enriched uranium fuel elements.

$4 / 7 / 53$ Started irradiation of lithium-aluminum targets for tritium production in DR Reactor. Program completed March 1955.

$12 / 53$ Initiated shipping of lithium-aluminum target elements to Building 108-B for tritium extraction.

$3 / 15 / 54$ Started irradiation of thorium for $\mathrm{U}-233$ production in $\mathrm{H}$ Reactor. The program was completed during October 1955.

1/4/55 KW Reactor startup

3/11/55 Restart KW Reactor after tube replacement

4/17/55 KE Reactor startup

1956 Water plant equipment and water effluent system upgraded in all reactors to increase coolant flow and production capacity.

1958 Started loading reactors with internally and externally cooled fuel elements (annular designed fuel element).

$12 / 60$ Exhaust air from $F, C$, and $B$ Reactors routed through absolute filters. Exhaust air was previously unfiltered.

1/61 Exhaust air from DR, D, H, KE, and KW Reactors routed through absolute filters. Exhaust air was previously unfiltered.

5/28/61 H Reactor charged with lithium-aluminum alloy target elements. Program continued for eight cycles and concluded in September 1964 .

6/1/61 Initiated high-alum feed water treatment, which reduced quantity of radioactive effluents to the river.

10/61 Charcoal filters installed on exhaust air from eight older reactors to capture any radioactive halogens generated by neutron activation. 
5/2/63 Charged KW Reactor with 1ithium target elements made of lithium-aluminum alloy

12/31/63 N Reactor startup

9/22/64 H Reactor 1ithium-aluminum al loy target element program concluded with discharge of eighth cycle

12/30/64 DR Reactor shutdown

4/21/65 H Reactor shutdown

6/25/65 F Reactor shutdown

$6 / 26 / 67$ D Reactor shutdown

2/12/68 B Reactor shutdown

4/25/69 C Reactor shutdown

2/1/70 KW Reactor shutdown

1/28/71 KE Reactor shutdown

$3 / 87$ N Reactor in cold standby.

After the first few years of operations, the power levels of the reactors were gradualiy increased, which stressed the reactor fuel and resulted in fuel failures (Table 3.1). The earliest fuel failure occurred in 1948, but frequent failures began in 1951, peaking at 242 in 1955. By 1960 the failures had dropped below 100 per year (DeNeal 1965).

\subsection{EFFLUENTS}

The main disposal problem in the 100 Area was the enormous volume of water that became radioactive after passage through the pile. Most of the radionuclides involved were short-lived, so the water was sent to a retention pond that had a series of baffles arranged such that the average unit volume of water remained in the pond at least 2.5 hours; this time was normally doubled by using two basins in parallel. From the time water left the graphite pile until it left the retention basin, the activity was reduced by a factor of 150,000 to 200,000 through radioactive decay. The water was then discharged into the mainstream of the Columbia River where it was diluted. Continuous checks of the level of radioactivity were made on all 
TABLE 3.1. Fue1 and Target Element Failures in Hanford Reactors

$\begin{array}{ccc}c \gamma & & \begin{array}{c}\text { Total } \\ \text { Failures }\end{array} \\ 1948 & & 2 \\ 1949 & 0 \\ 1950 & 3 \\ 1951 & 115 \\ 1952 & 142 \\ 1953 & 93 \\ 1954 & 211 \\ 1955 & 242 \\ 1956 & 191 \\ 1957 & 201 \\ 1958 & 174 \\ 1959 & 71 \\ 1960 & 130 \\ 1961 & 86 \\ 1962 & 95 \\ 1963 & 68 \\ 1964 & 97 \\ 1965 & 89 \\ 1966 & 17 \\ 1967 & 29 \\ 1968 & 20 \\ 1969 & 16\end{array}$

effluent water discharged to the river. In general, in the first years of Hanford Site operation the activity of the water did not cause the estimated immersion dose rate to exceed 50 mrep per 24 -hour period before dilution. That value was intended to keep the radiation dose to fish within the same limits used for workers, which was 300 mrep per week.

The release of radioactive materials in reactor effluent water increased with increasing production rates until around 1961 when a change in the water 
treatment process was implemented to reduce releases. A high-alum feed water treatment began July 1, 1961, and efforts to keep reactor effluent activity down continued thereafter (Geier 1966). The new treatment system reduced effluent radioactivity by approximately a factor of two.

The helium system described in Section 3.2.4 was a closed-10op system; however, impurities in the system became radioactive, and fuel ruptures contributed moisture and radioactive gases to the system. These impurities were removed before the helium was recycled back to the reactor and were exhausted to a tunnel under the gas purification building and then on to the stack. Figure 3.8 shows the air exhaust system for $C$ Reactor. The presence of filters indicates that this diagram is post-1961; prior to 1960 air was released without any filtration. The nominal flow capacity of the exhaust systems ranged from 85,000 to $160,000 \mathrm{cfm}$ for a 11 the reactors except KE, KW, and N. Figure 3.9 shows the reactor effluent systems. 


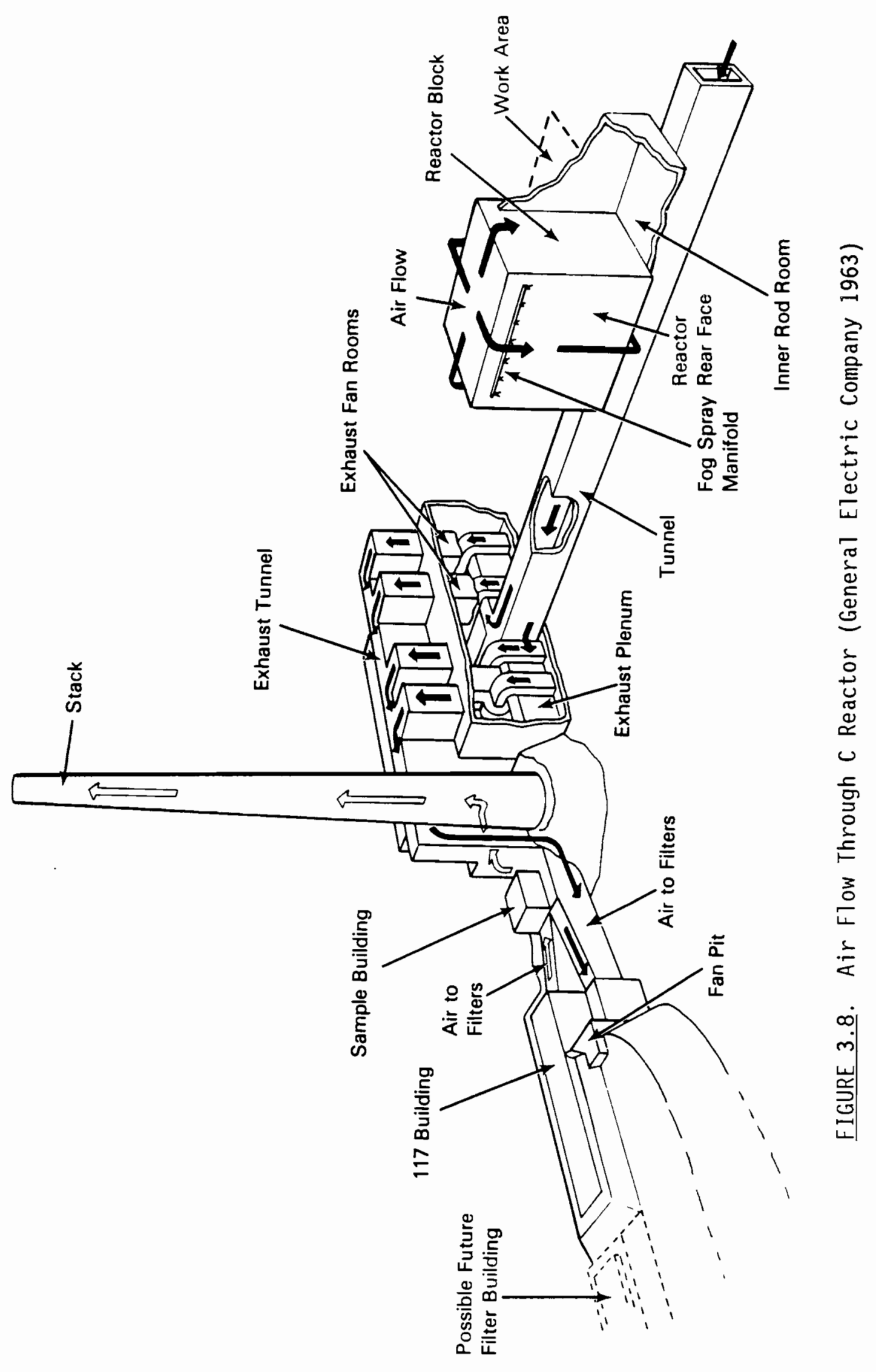




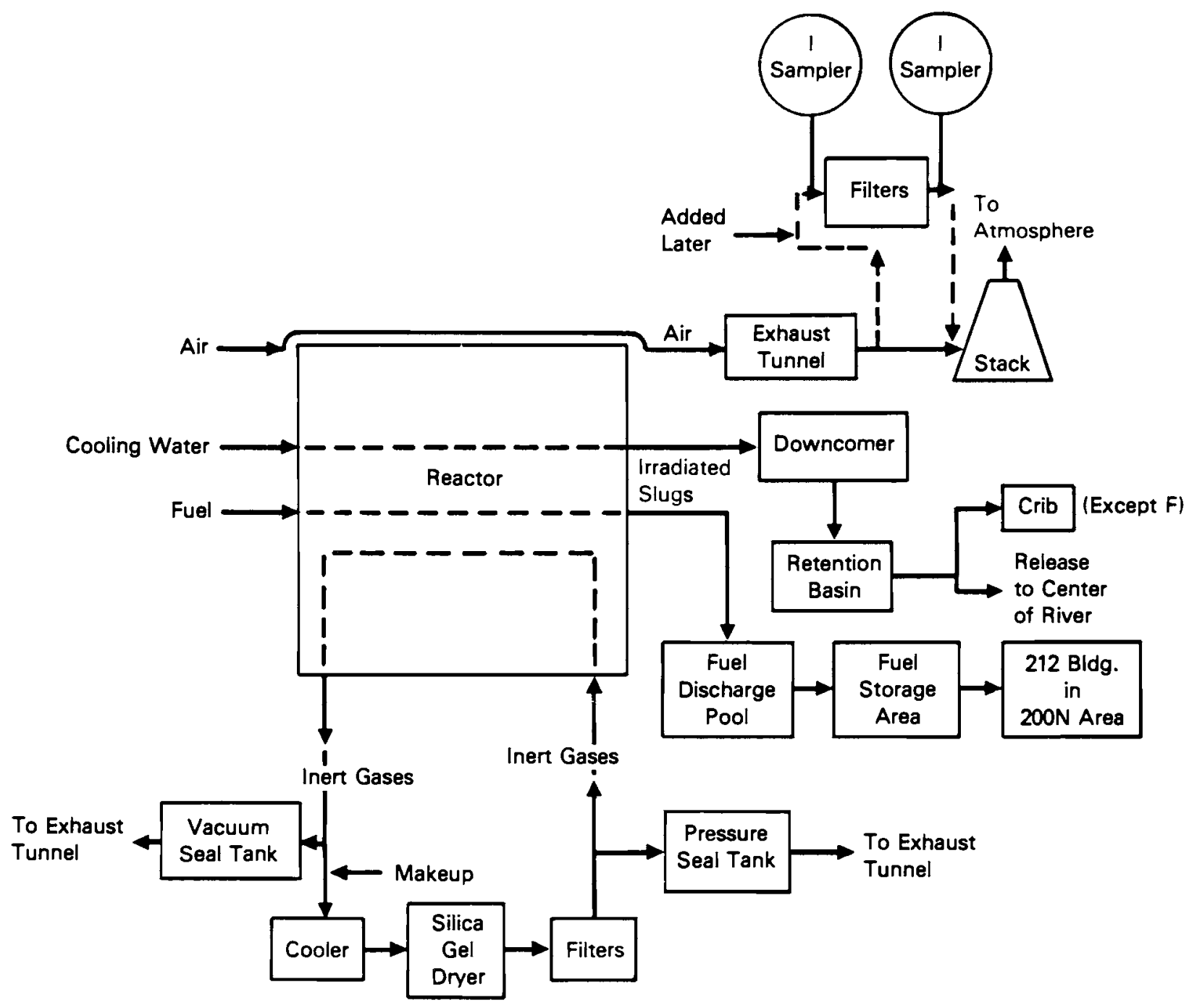

FIGURE 3.9. Reactor Effluent System Flow Diagram 


\subsection{FUEL SEPARATIONS}

Separations plants were used to chemically extract plutonium contained in the fuel discharged from the reactors. Initially, three large buildings ( $T, B$, and $U$ Plants) were constructed in the 200 Areas, each of which was to handle fuel from one of the first three reactors ( $B, D$, and $F$ ). However, because the capacity and recovery efficiency of the separations process were better than estimates made on the basis of small-scale experiments, only $T$ and B Plants were needed. U Plant was eventually used for uranium recovery.

The bismuth phosphate process was the first one used to chemically separate the plutonium from uranium and fission products. Dissolution of the irradiated fuel and chemical separation of the plutonium took place in the $B$ and $T$ Plants. The final plutonium product was concentrated in the $231-Z$ Building. The REDOX (reduction oxidation) and PUREX (plutonium-uranium extraction) processes were developed later; and the $S$ and $A$ Plants were built for these respective processes.

Each of the separations processes is described in the next section, followed by a discussion of the facilities used. A timetable of operations and significant events affecting radioactive emissions is given, followed by a discussion of effluents from the separations processes. The information on processes and effluents was taken primarily from Hanthorn (1957). Facility descriptions were obtained from Parker (1947) for B and T Plants and General Electric Company (195la) and General Electric Company (1955) for the REDOX and PUREX Plants, respectively.

\subsection{PROCESS DESCRIPTIONS}

All Hanford Site fuel separation processes were based on dissolving the irradiated uranium metal in nitric acid and conducting multiple purification operations on the resultant aqueous nitrate solution. The irradiated uranium fuel elements were brought into the railroad cell of the canyon building (see Section 4.2) in buckets in the cask cars. The cask lids were removed with the canyon crane, and the buckets of fuel elements were picked up one at a time and lowered into the dissolver chute. In the chute, bars and tipping 
lugs tilted the buckets to empty them. The fuel elements fell into the dissolver, the buckets were removed and replaced in the casks, and the whole process was repeated until the full amount had been added.

The metal was charged into the dissolvers, located in B and T Plants, in batches of 3 long tons initially ( 8 buckets of 105 slugs each). In order to increase the rate of dissolution by use of a large amount of reacting surface, a metal heel of approximately one long ton was carried in the dissolver (E. I. du Pont de Nemours and Company 1944).

The aluminum jackets were dissolved with a sodium hydroxide solution to which sodium nitrate was added to avoid formation of too much hydrogen. The resulting sodium aluminate-sodium nitrate solution was jetted (transferred via a steam jet) to waste. The remaining uranium metal slugs were rinsed with water and dissolved in 50 to $60 \%$ nitric acid. Excess uranium metal, referred to as a heel, usually remained in the dissolver; completion of the reaction was determined by specific gravity, measured with a pair of bubbler tubes immersed in the solution.

\subsubsection{Bismuth Phosphate Process}

In the bismuth phosphate precipitation process, no attempt was made to recover the uranium. Sodium nitrate solution was added to a batch of dissolver solution to ensure that the plutonium present had a valence of +4 , then bismuth nitrate and phosphoric acid were added. The resulting precipitate of bismuth phosphate carried the plutonium with it. This precipitate was separated from the solution in a solid-bowl centrifuge, and the solution was jetted to waste. The precipitate was washed in the centrifuge and dissolved in strong nitric acid. The valence of the plutonium was then adjusted to +6 by addition of a dichromate solution, and a precipitate of bismuth phosphate was again formed. This time the precipitate held some of the fission products that were not extracted in the first liquid waste stream, but the plutonium remained in solution. These precipitation cycles were repeated twice. Figure 4.1 shows the bismuth phosphate process used in B Plant until 1952 and T Plant until 1956. 


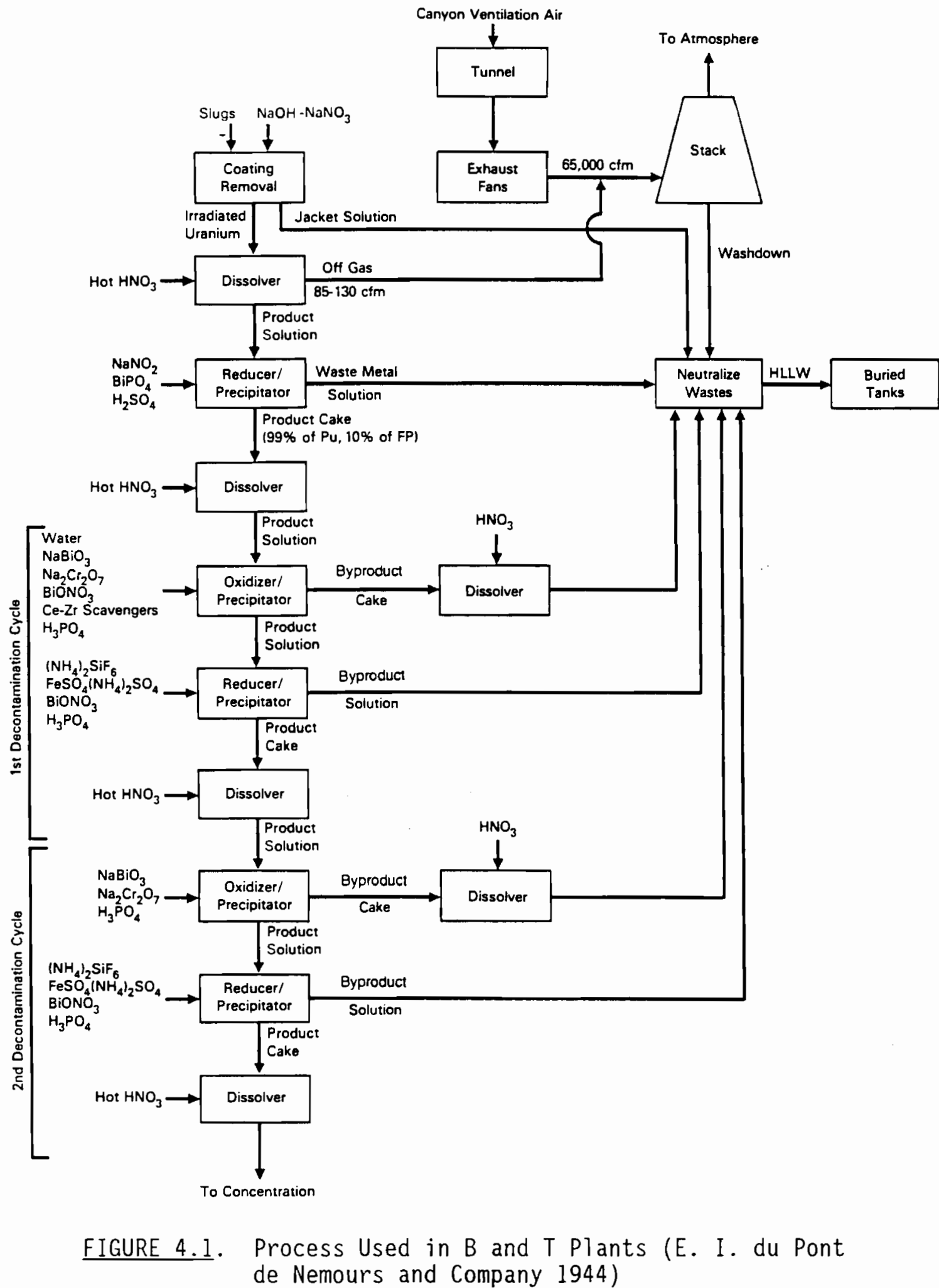


The product from the bismuth phosphate process was a dilute plutonium solution. In the Concentration Building (224 Building), the product was purified, the product volume was reduced, and the carrier was switched from bismuth phosphate to lanthanum fluoride. The steps in this process are (Parker 1947):

1. The product solution was received from the canyon building, oxidized with sodium bismuthate, and jetted to a tank.

2. $\mathrm{H}_{3} \mathrm{PO}_{4}$ was added to the solution, which caused plutonium to remain in solution and by-product to precipitate. A centrifuge separated the product from by-product. Product solution was passed to a catch tank. By-product cake was dissolved out of the centrifuge with nitric acid and transferred to a waste neutralization tank, and then disposed of.

3. Hydrogen fluoride and lanthanum salt were added to the oxidized product solution, which again precipitated by-product. Centrifugation again separated cake from solution, and product was jetted to a catch tank while by-product was dissolved out of the centrifuge, then sent to waste as before.

4. Plutonium and lanthanum fluoride were precipitated out of solution by adding $\mathrm{H}_{2} \mathrm{C}_{2} \mathrm{O}_{4}$, HF, and La salt. Waste solution was disposed of via centrifuge, catch tank, and waste neutralization.

5. The product cake was washed out of the centrifuge with water and $\mathrm{KOH}$ and is jetted to a tank. Plutonium fluoride was metathesized to $\mathrm{Pu}(\mathrm{OH})_{4}$ by digesting with $\mathrm{KOH}$ and heat in the tank.

6. The solid hydroxides were separated out in a centrifuge, then dissolved in nitric acid, forming plutonium nitrate. This product solution was removed from the building and transferred in cans to the Isolation Building.

The following description of the isolation process was taken from E. I. du Pont de Nemours and Company (1944):

The $\mathrm{La}\left(\mathrm{NO}_{3}\right)_{3}-\mathrm{Pu}\left(\mathrm{NO}_{3}\right)_{4}$ solution sent to the isolation building contains about four times as much lanthanum as plutonium and also smaller amounts of other impurities ( $\mathrm{K}, \mathrm{Ca}, \mathrm{Bi}, \mathrm{Fe}, \mathrm{Cr}$, etc.). The isolation process frees the product of the lanthanum and other impurities and results in a final product nitrate at 1east $95 \%$ pure. Two plutonium peroxide precipitations are used to accomplish this process.

The product solution received from the Concentration Building is first filtered and then treated with ammonium sulfite to reduce any hexavalent plutonium that might be present, then sulfate added 
before the precipitation to provide conditions favorable to rapid settling of the plutonium peroxide. The precipitate is washed and dissolved in nitric acid, the solution filtered, and the plutonium then reprecipitated as the peroxide. This second precipitate is washed, dissolved in nitric acid, with decomposition of the peroxide, and the plutonium nitrate solution concentrated in a still. This concentrated solution was transferred to a sample can, where it is further concentrated by evaporation to a thick paste.

The final isolated product is usually about $98 \%$ pure; the major soluble impurities are $\mathrm{La}, \mathrm{Fe}$, and $\mathrm{Cr}$. Insoluble impurities are also often associated in variable amounts with the final product. They consist mainly of $\mathrm{SiO}_{2}$ (from the filter media and filter aid used) and meta-stannic acid (from the use of tin-stabilized $\mathrm{H}_{2} \mathrm{O}_{2}$ reagent).

\subsubsection{REDOX Process}

The REDOX process was chosen to replace the bismuth phosphate process for several reasons: lower cost, improved throughput, recovery of uranium, and more than $98 \%$ plutonium recovery. In the REDOX process, uranium and plutonium in the dissolver solution were adjusted to the +6 valence state and fed to the center point of a solvent extraction column. Hexone ran countercurrently through the column and extracted uranium and plutonium from the aqueous phase into the organic phase. The extraction was enhanced by salting the aqueous phase in the column with aluminum nitrate. The fission products remained in the aqueous phase. In the second column, the organic solution containing the uranium and plutonium was fed at the middle and contacted with an aluminum nitrate solution containing a reducing agent, ferrous ion. Plutonium was reduced to the +3 valence state, which extracted into the aqueous solution. The remaining fission products were split about half and half in this column. The uranium solution in hexone was extracted with plain water in a third column. Some fission products stayed with the hexone at this point and were removed in the hexone recovery still. The uranium solution was then concentrated to feed strength and given two more cycles of solvent extraction followed by evaporation to reduce product volume.

Plutonium in the +3 valence state from the second extraction cycle was in an aqueous solution. The solution was oxidized by addition of nitric acid and sodium dichromate to put plutonium in the +4 or +6 valence state so that it could be extracted with hexone and further decontaminated. After 
residual traces of fission products were removed from the plutonium stream, the aqueous plutonium product was concentrated for shipment to the plutonium finishing facilities.

\subsubsection{PUREX ProcesS}

The PUREX process was an organic solvent extraction process like the REDOX process. Major differences between PUREX and REDOX include use of tributyl phosphate in kerosene as the extraction agent instead of hexone, strong nitric acid as the salting agent instead of aluminum nitrate, pulse columns instead of packed columns as solvent extraction contactors, and nitric acid recovery in the dissolution step.

\subsubsection{TBP Process}

The uranium recovery process, in which uranium in the waste tanks from the bismuth phosphate process was recovered, used a separation process similar to PUREX except that plutonium was not extracted. The waste tanks were sluiced with their own supernatant to produce a slurry that was then pumped to $U \mathrm{Pl}$ ant. A counter-current extraction column using organic solutions of tributyl phosphate contacting the aqueous stream preferentially attracted uranium into the organics, separating it from other fission products and small amounts of plutonium. In another column, uranium was stripped back into the aqueous phase. Uranyl nitrate was converted to $\mathrm{UO}_{3}$ by calcination at high temperatures in the $\mathrm{UO}_{3} \mathrm{Plant}$.

\subsection{FACILITY DESCRIPTIONS}

The separations plants are large, concrete buildings, in which the process equipment is arranged in small rooms, called cells, that are arranged in a row or rows in a long building spanned by a traveling crane. The cells are topped with 4-ft concrete blocks that are removable by crane. Above the blocks is a space equal in height to the cell depth, providing headroom for manipulating the process equipment during maintenance operations. The heavy concrete shielding walls enclose this space up to the level of the crane rails, giving the appearance of a canyon. The buildings are called canyon buildings, and the process portion of the buildings is referred to as the canyon. Figure 4.2 shows the B and T Plant canyons. The top face of the 


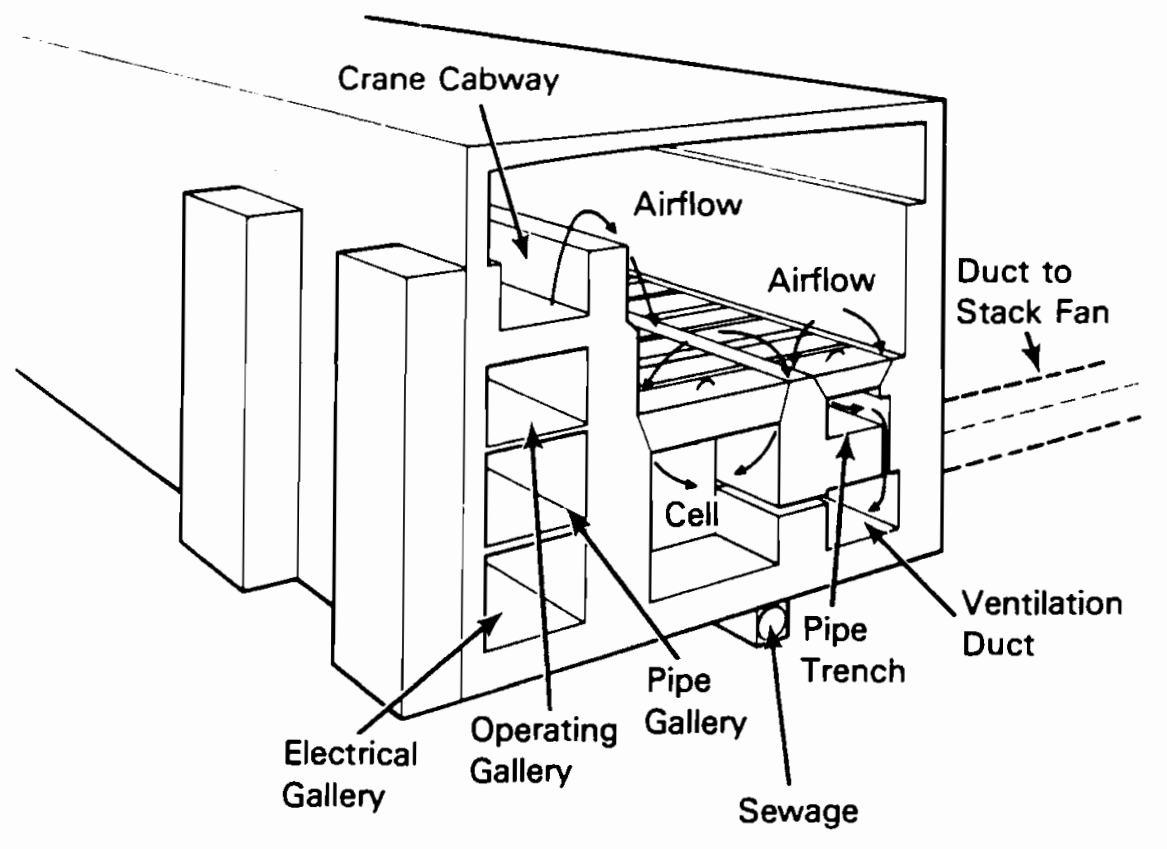

FIGURE 4.2. Isometric Diagram of $B$ and $T$ Plant Canyon

shielding blocks and adjacent floor levels are called the canyon deck. The deck level is a few feet above grade, so most of the cell depth is underground. The only access to most of the cells is at the top with the blocks removed; however, one cell in each canyon is a railroad cell that is also entered from one side by a railroad spur. Outside the building, the spur is shielded by earth embankments on both sides.

\subsubsection{B and T Plants}

Design of separation plants was based on four considerations:

1. adequate protection of personnel from radiation

2. remote operation of process equipment

3 . remote maintenance of process equipment

4. flexibility of arrangement to facilitate process changes without redesign of building.

Radiation shielding was provided by massive concrete walls that served as the structural portions of the building. Remote operations were performed 
with electrically driven motors and numerous recording and indicating instruments to follow process parameters.

Remote maintenance was facilitated by designing the process piping as single lines without T's or multiple connections, and by the use of steam jet ejectors for all process transfers. All sections of process piping and all pieces of equipment were supplied with handles and were bal anced so that any piece could be removed and another dropped in its place by the crane.

The canyon crane was a 75-ton capacity, electrically operated, overhead railway crane that could move its hooks, impact wrenches, and grabbers in al1 three directions. The crane cab was located behind a 5 -ft concrete wall for protection against direct radiation from the open cells. The cab was covered with 4.5 in. of steel for protection against radiation scattering over the wall. All viewing was done through fine optical periscopes that provided a. view of all parts of the canyon proper.

A second 10-ton capacity crane was on the same rails as the large crane and could be used when the radiation level was low enough that the work could be viewed directly.

The canyons consisted of a row of 20 concrete sections. Each section was $40 \mathrm{ft}$ wide and divided into two cells. Twelve of these sections contained a standard arrangement of process equipment: a precipitator, centrifuge, catch tank, and solution tank. The centrifuge and catch tank were in one cell of the section, and the precipitator and solution tank were in the other cell. Most of the canyon operations for B and T Plants could be accomplished with this configuration. For example, a product was precipitated in the precipitator; the solution was jetted into the centrifuge, where the product cake was caught, and the supernatant by-product waste solution overflowed to the catch tank, from which it was jetted to the waste storage tanks. The product cake was then dissolved out of the centrifuge and caught in the solution tank.

The standard cell was a room below the canyon deck level that was about $13 \times 18 \times 22 \mathrm{ft}$. It had 7-ft-thick walls, and the cover consisted of four 
6-ft-thick blocks each weighing about 36 tons. The tops of the blocks formed a part of the canyon deck when in place. The functions of each of the 40 cells are shown in Table 4.1 .

A pipe trench ran the length of the canyon, from sections 3 to 20, and contained the pipes that carried the solutions from cell to cell. The trench was covered with $4.5-\mathrm{ft}$-thick concrete blocks, the tops of which also form part of the canyon deck when in place. Figure 4.2 shows the pipe trench and galleries.

The operating gallery was on the level of the canyon deck but was completely separated from it by a 7 -ft-thick concrete wall. At each section was an operating and instrument board for complete remote operation of the process equipment. Tanks for weighing chemicals that were added in the process were located there.

The pipe gallery was directly under the operating gallery, separated from the cells by a 9-ft-thick concrete wall. All chemical, electrical, steam, water, and instrument lines entered the cells from this gallery. All lines going through the $9-\mathrm{ft}$ wall were offset on the way through so that no direct radiation from the cell could enter the pipe gallery; therefore, remote maintenance was not required in this location and fixtures were standard.

The electrical gallery was under the pipe gallery, al1 electrical and steam 1 ines entered the building through this gallery before entering the pipe gallery.

A ventilation tunnel was located under the pipe trench. Air was pulled from all cells to the exhaust fans and stack. Cells were under negative pressure with respect to the canyon itself. Figure 4.3 shows the ventilation system of the $B$ and $T$ canyon buildings.

\subsubsection{Concentration Building}

A plutonium product concentration building was located behind each canyon building opposite sections 19 and 20 . This building was more like a typical chemical plant, because the product solutions handled there had been decontaminated to an extent where the radiation hazards (primarily alpha 
TABLE 4.1. Functions of Cells for $B$ and $T$ Plants (see Figure 4.3)

Cell No.

$1 \mathrm{L \& R}$

$2 \mathrm{~L}$

$2 \mathrm{R}$

$3 L \& R$, $4 L$

$4 R$

5 L\&R

6 L\&R

7 L\&R

$8 L \& R$

9 L\&R

10 L\&R

11 L\&R

$12 L \& R$

13 L\&R

14 L\&R

15 L\&R

$16 L \& R$

$17 L \& R$

18 L\&R

19 L\&R

$20 \mathrm{L \& R}$
Designed Use

Empty cells for storage of defective hot equipment

Railroad tunnel for cask car entry

Filled with water for dunking empty buckets and storing fractured fuel elements

Dissolver tanks, coating removal, metal reduction

Metal solution storage

Sewage disposal and storage tanks

Spare standard cell

Standard cell for extraction

Standard cell for extraction

Treatment of waste metal solution before jetting to storage Treatment of waste metal solution before jetting to storage Spare section, unequipped

Storage and oxidation of metal solution

First decontamination cycle, by-product precipitation

First decontamination cycle, product precipitation

Treatment of decontamination wastes from all cycles

Second decontamination cycle, by-product precipitation

Second decontamination cycle, product precipitation

Third decontamination cycle, not used

Third decontamination cycle, not used

Spare section, unequipped 


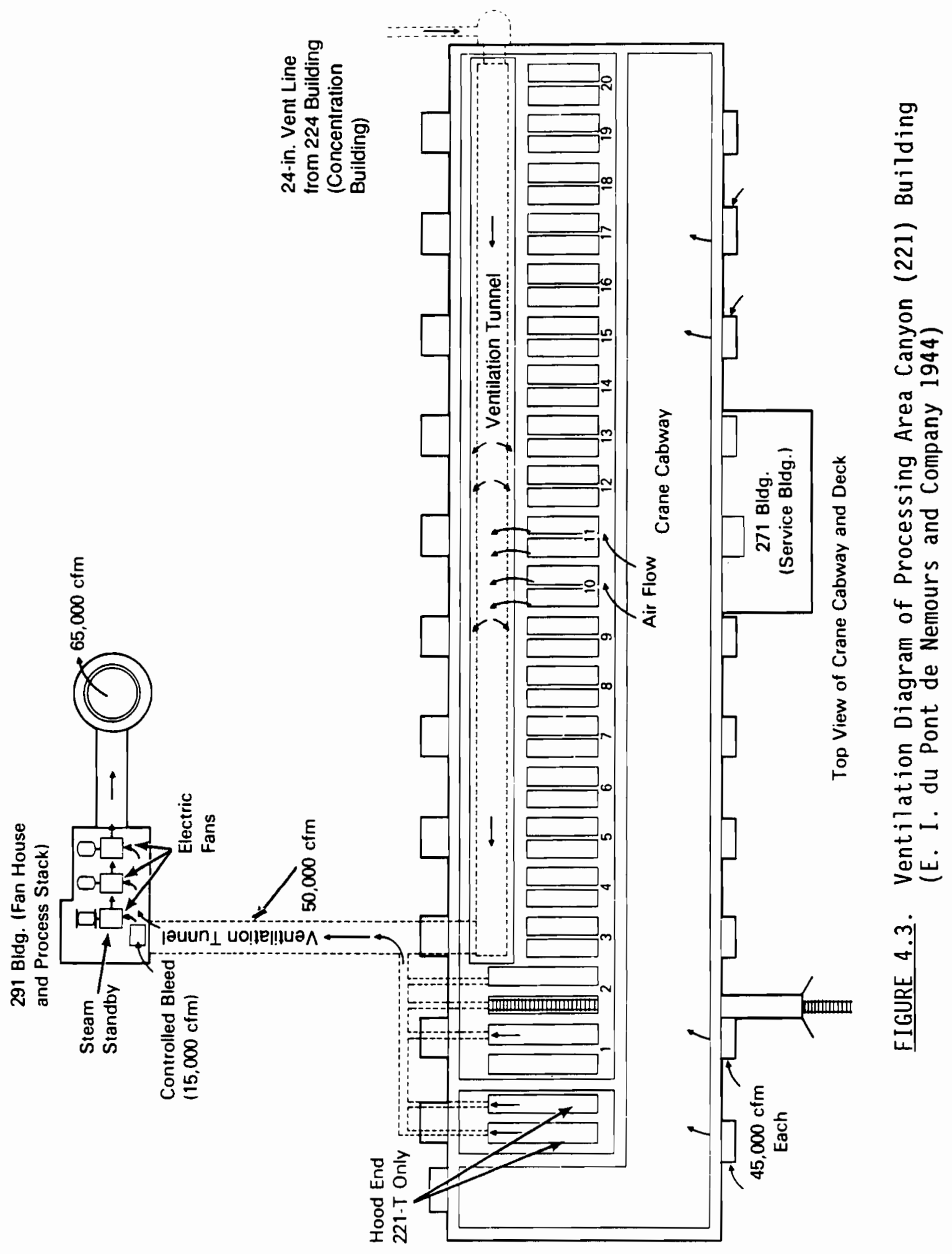


radiation whose penetrating power is less than beta or gamma radiation) were not as great. The six cells in the building were designated $A$ through $F$. Cells $A, B, D$, and $E$ contained the standard cell grouping of a precipitator, centrifuge, catch tank, and solution tank. C cell was on two levels, the lower of which contained a receiving tank to receive the solutions from sections 17 or 19 of the canyon. Cell C also contained a sump tank to receive the building's cell drainage, and a tank where the waste solutions were treated before transfer to storage. Cell $\mathrm{F}$ contained three agitated tanks, one unagitated tank, two centrifuges, and a receiving tank in a separated portion of the cell, where the solution leaving the building for transfer to the Isolation Building was placed in a transfer can and carrier. Uses of the cells are listed in Table 4.2.

Because the radiation hazard was reduced in solutions reaching this building, the process tanks and piping were of conventional construction, and access to the cells was possible at certain times. Walls around and between cells were of $1-\mathrm{ft}$-thick concrete. Cells were on the ground floor of one side of the building and extended up to the roof. The ground floor of the remainder of the building contained shops, offices, and locker rooms. The second floor contained the pipe gallery, A to $E$ sample rooms, and the $F$ cell operating gallery. The third floor contained the $A$ to $E$ cell operating gallery and the chemical makeup and weigh tanks.

TABLE 4.2. Functions of Cells in Concentration Building

\begin{tabular}{cl} 
Cell & \multicolumn{1}{c}{ Designated Use } \\
A & Cross-over process, by-product precipitation with $\mathrm{BiPO}_{4}$ \\
$\mathrm{~B}$ & Spare cell, fully equipped \\
C & Receive solution from canyon, sewage disposal, waste treatment \\
D & Cross-over process, by-product precipitation with $\mathrm{LaF}_{3}$ \\
$\mathrm{E}$ & Cross-over process, product precipitation \\
$\mathrm{F}$ & Metathesis and transfer out of building
\end{tabular}


Access to cells $A$ to $E$ was through doors on the outside rear of the building. The centrifuges in $A, B, D$, and $E$ cells were on a balcony in each cell that was entered through the sample rooms. The $F$ cell was entered through the locker room on the ground floor.

Ventilation was supplied to each cell by fans in the pipe gallery and was exhausted through roof fans on each cell. All process tanks were vented to the area stack exhaust system.

In the $A$ to $E$ cell section of the building, the cell walls did not extend to the ceiling, so a hand-operated crane could travel over A to E cell for moving heavy equipment. The crane was operated from the balcony surrounding the $A$ to $E$ cell section.

\subsubsection{REDOX Plant (S Plant)}

The REDOX process differs from the bismuth phosphate process in that all steps except metal dissolving and feed preparation are conducted on a continuous basis, requiring the use of a great variety and number of automatic control instruments. All steps in the bismuth phosphate process are batch.

The REDOX Plant (Figure 4.4) was designed to process an average of 2.5 short tons of uranium per day. The process difference between REDOX and bismuth phosphate resulted in several advantages: less high-level liquid waste generation, uranium recovery, greater decontamination factor, and increased processing rate. However, the use of hexone as a solvent posed an extra fire and explosion hazard that the bismuth phosphate process did not have.

Because hexone vapors are explosive when mixed with air within the limits of 1.34 and $8.0 \%$ by volume at room temperature (General Electric Company 1951 a), several safety features for the prevention of fire and/or explosion were incorporated into the REDOX Plant. Among these were inert-gas blanketing of solvent-containing vessels, adequate process area ventilation, and use of explosion-proof electrical equipment in the solvent area. The plant also had fire detection and water-fog fire-control systems. 


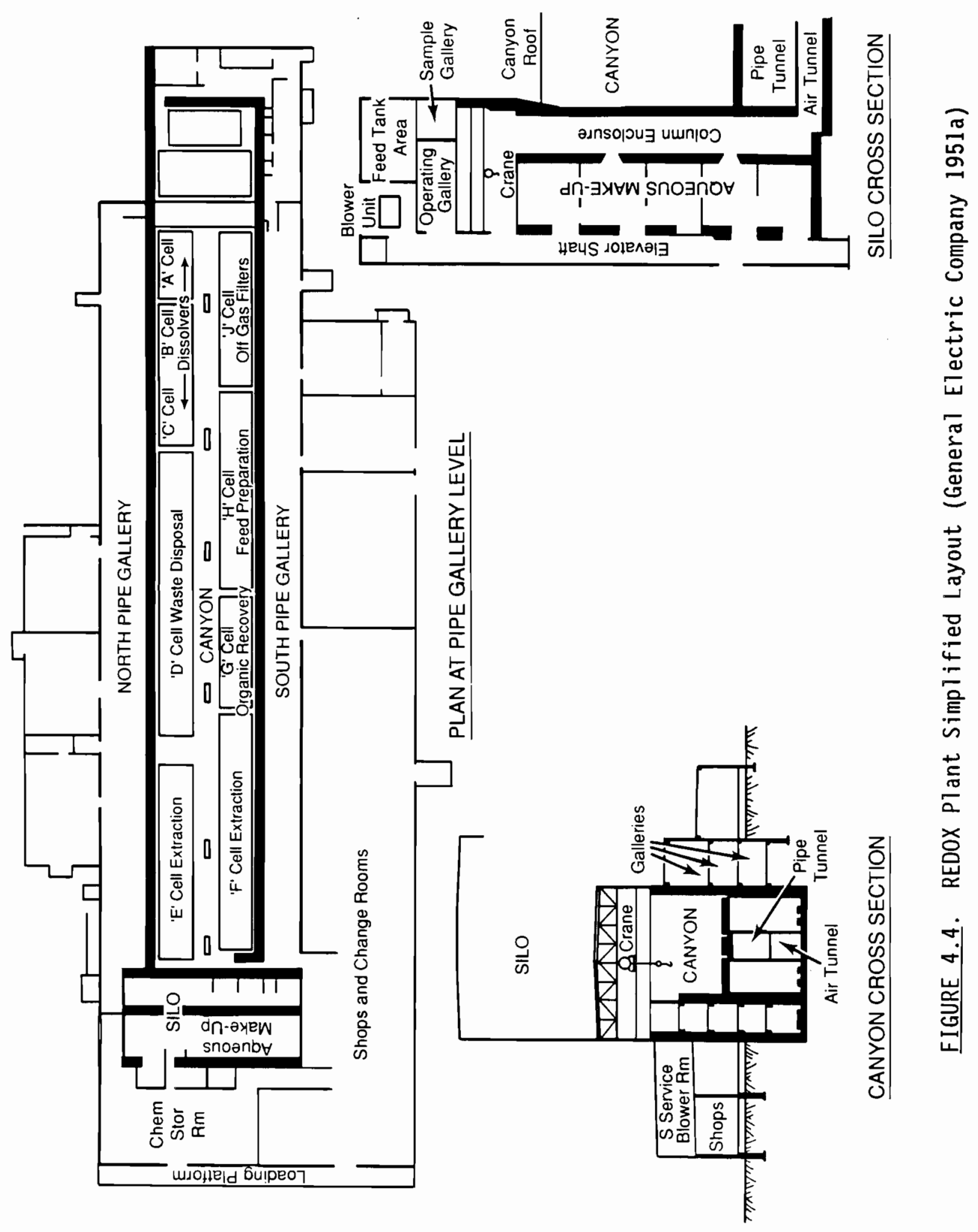


A silo was built at one end of the canyon in the REDOX Plant to house tall solvent extraction columns and auxiliary equipment. The silo is about $132 \mathrm{ft}$ high, $84 \mathrm{ft}$ long, and $40 \mathrm{ft}$ wide.

\subsubsection{PUREX Plant (A Plant)}

The PUREX Plant, or A Plant (Figures 4.5 and 4.6 ), is similar to the $B$ and $\mathrm{T} P \mathrm{Plants}$ and REDOX in that it also consists of a large canyon divided into many cells. The plant was built between April 1953 and October 1955 and began operating in January 1956.

The PUREX process was similar to the REDOX process in that processing operations are conducted on a continuous basis, except for the metal dissolving and feed preparation stages. However, there are several major process differences, including use of nitric acid as a salting agent, kerosene as the organic solvent, pulse column contactors, and nitric acid recovery by distillation.

The PUREX Plant was made of reinforced concrete with overall dimensions of approximately $118 \mathrm{ft}$ wide by $1005 \mathrm{ft}$ long by $104 \mathrm{ft}$ high. Nominal design capacity for the plant was 8.33 short tons uranium per day as opposed to 2.5 for the REDOX Plant.

The quantity of air supplied to the various zones ranges from about 1 to 2 air changes per hour (in the air space above the canyon deck) to about 11 air changes per hour (in the uranium concentrator cells) (General Electric Company 1955).

The operation of PUREX Plant was nearly continuous. However, on two occasions special limited campaigns were conducted to process thorium for the recovery of $233 \mathrm{U}$ (a fissionable isotope of uranium). The thorium had been irradiated in the Hanford reactors. The recovery campaigns occurred in 1966 and 1971. The thorium also was extracted and partially decontaminated. The waste composition was similar to that from the typical PUREX process except that it contained small quantities of thorium and $233 \mathrm{U}$ instead of uranium and plutonium (U.S. Department of Energy 1987). 


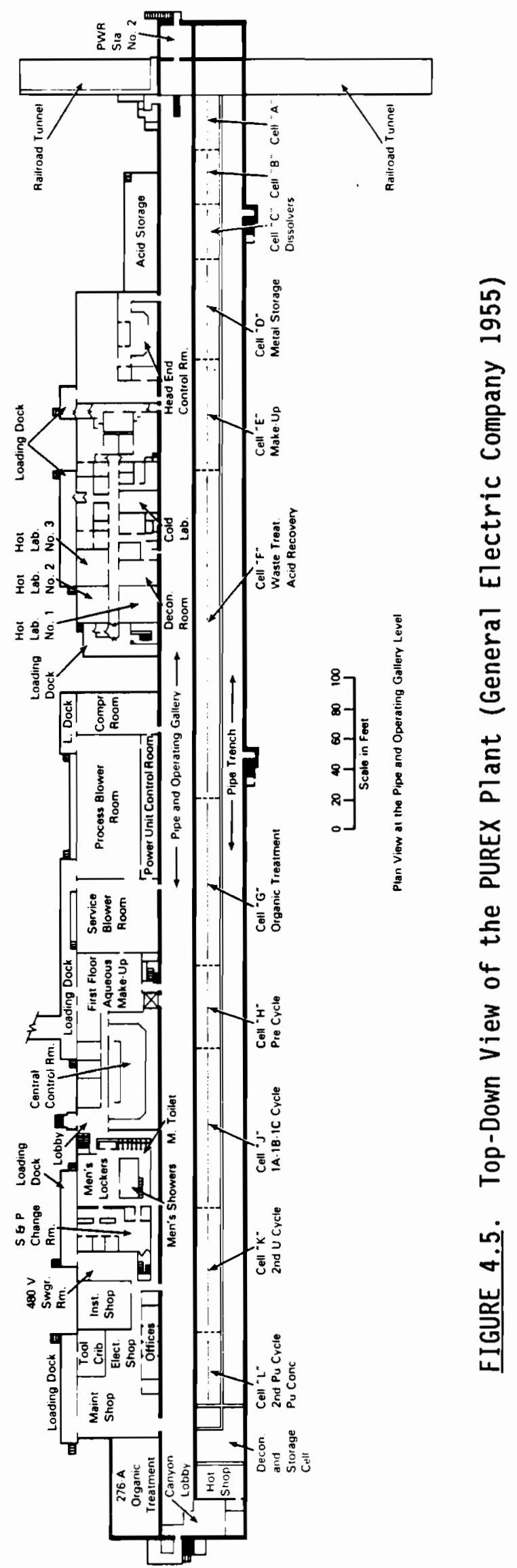

4.16 


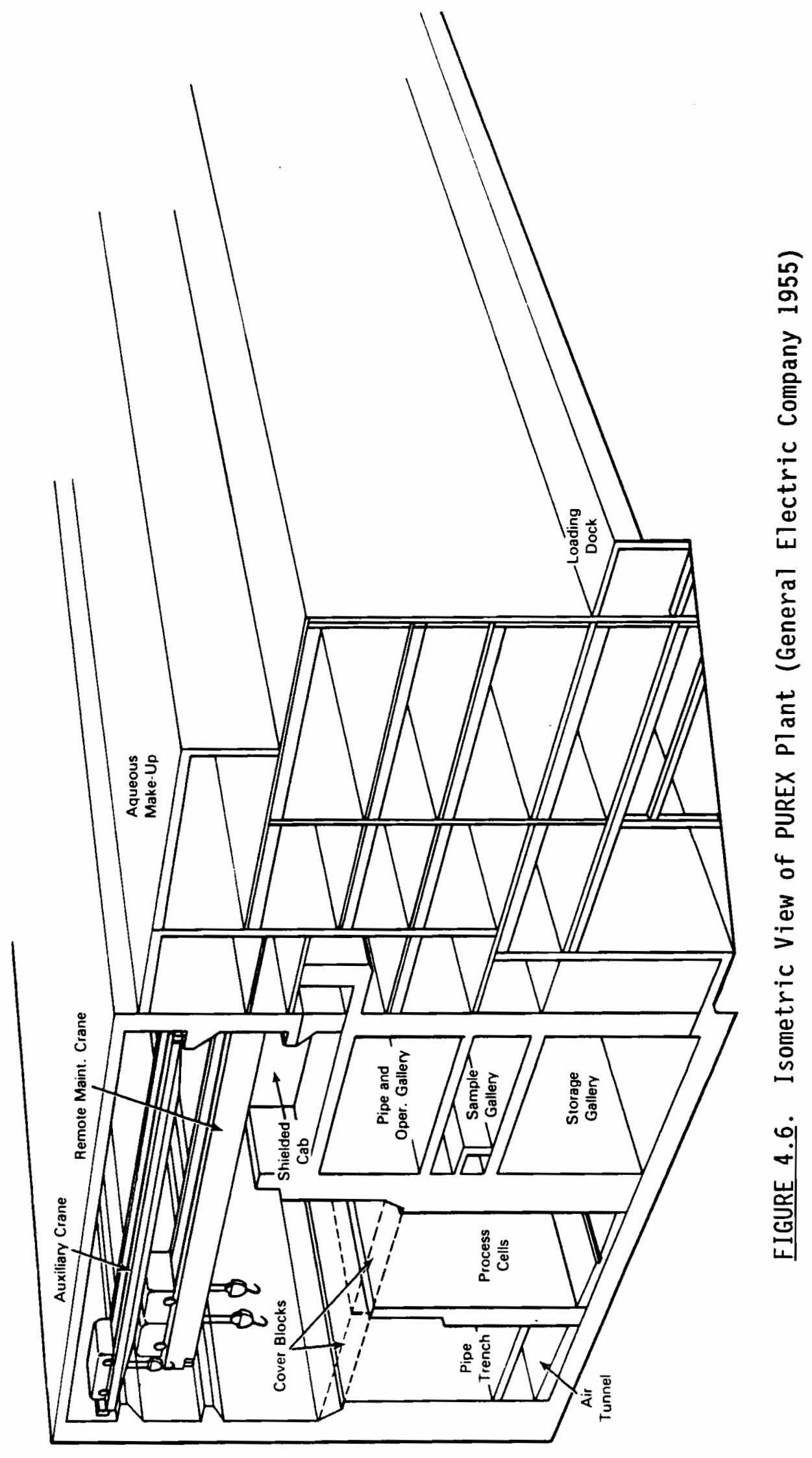




\subsubsection{Plant (Hot Semiworks)}

The initial function of the hot semiworks, or C Plant, was to obtain experimental data on separation processes and equipment (Evans and Tomlinson 1954). The main process building for these activities was 201-C, which consisted of three concrete cells located below grade with the middle cell extending above grade as a silo for housing separation equipment such as extraction columns. The above-grade areas contained services for the facility. Next to the building was a shop for working on lightly contaminated equipment and an air treatment room.

The semiworks facility started up in 1952 and operated as a pilot plant for the REDOX process until 1954. Then the facility was converted for use as a pilot plant for the PUREX process. The facility was shut down in 1956, and remained idle for the next 6 years. It was then decontaminated and modified and restarted in 1962 as a pilot plant for the recovery of cesium and strontium from high-level waste and operated in this mode until 1967, when the facility was retired. The cesium and strontium recovery process is described in Chapter 7.0.

\subsection{6 $\underline{\mathrm{U} \text { and } \mathrm{UO}_{3} \mathrm{Pl} \text { ants }}$}

High-level liquid waste from the bismuth phosphate process contained uranium from the separations process and was first stored in single-shel 1 tanks. The neutralization of this uranium waste to a slightly alkaline condition to prevent corrosion of the mild-steel-1ined tanks resulted in the precipitation of a sludge that contained about $75 \%$ of the uranium. To remove the uranium waste from the underground storage tanks, the precipitate was mined by sluicing with its own supernatant liquid and pumping the slurry to process vessels. The sludge was then dissolved in nitric acid and processed through a solvent extraction process using a solution of tributyl phosphate in kerosene. The process was similar to the PUREX process except that the small quantities of plutonium in the waste were not recovered.

The uranium recovery process operated from 1952 to 1958 in U Plant, one of the three facilities originally built for the bismuth phosphate process. $U \mathrm{Plant}$ was extensively modified to conduct the uranium recovery process. The main canyon is used to store failed equipment. 
Another nearby building, the $\mathrm{UO}_{3} \mathrm{Plant}$, was used to convert liquid uranium nitrate solution to a powdered uranium oxide $\left(\mathrm{UO}_{3}\right)$. . High-temperature $\left(400^{\circ} \mathrm{F}\right)$ decomposition pots were used to calcine the liquid to a powder. Figure 4.7 shows the relative size and location of the $\mathrm{U}$ and $\mathrm{UO}_{3} \mathrm{Pl}$ ants.

\subsection{IIMETABLE}

Major events affecting the fuel separations facilities are listed here.

12/44 T P7ant startup

4/45 B Plant startup

4/48 Water scrubber installed in B Plant

(McCullugh and Cartmell 1968).

5/48 B and T Plant water scrubber installed (Anderson 1974).

10/48 Sand filters installed on $\mathrm{T}$ and B Plants

(Roberts 1958).

10/50 Installation of first off-gas filter - silver reactor unit at $B$ Plant (McCullugh and

Cartme11 1968.

10/50 Fiberglass filters installed at B Plant (Roberts 1958).

12/50 Fiberglass filters installed at $\mathrm{T} P \mathrm{P}$ ant (Roberts 1958).

12/50 Silver reactors installed at T Plant

(Roberts 1958).

1952 C Plant started operations as REDOX pilot plant.

1/52 REDOX startup (Roberts 1958)

3/52 U Plant startup

10/52 B Plant shutdown

1954 C Plant switched to pilot plant for PUREX process.

3/54 Head-end flowsheet revised in effort to minimize ruthenium emissions (McCullugh and Cartmel1 1968). 


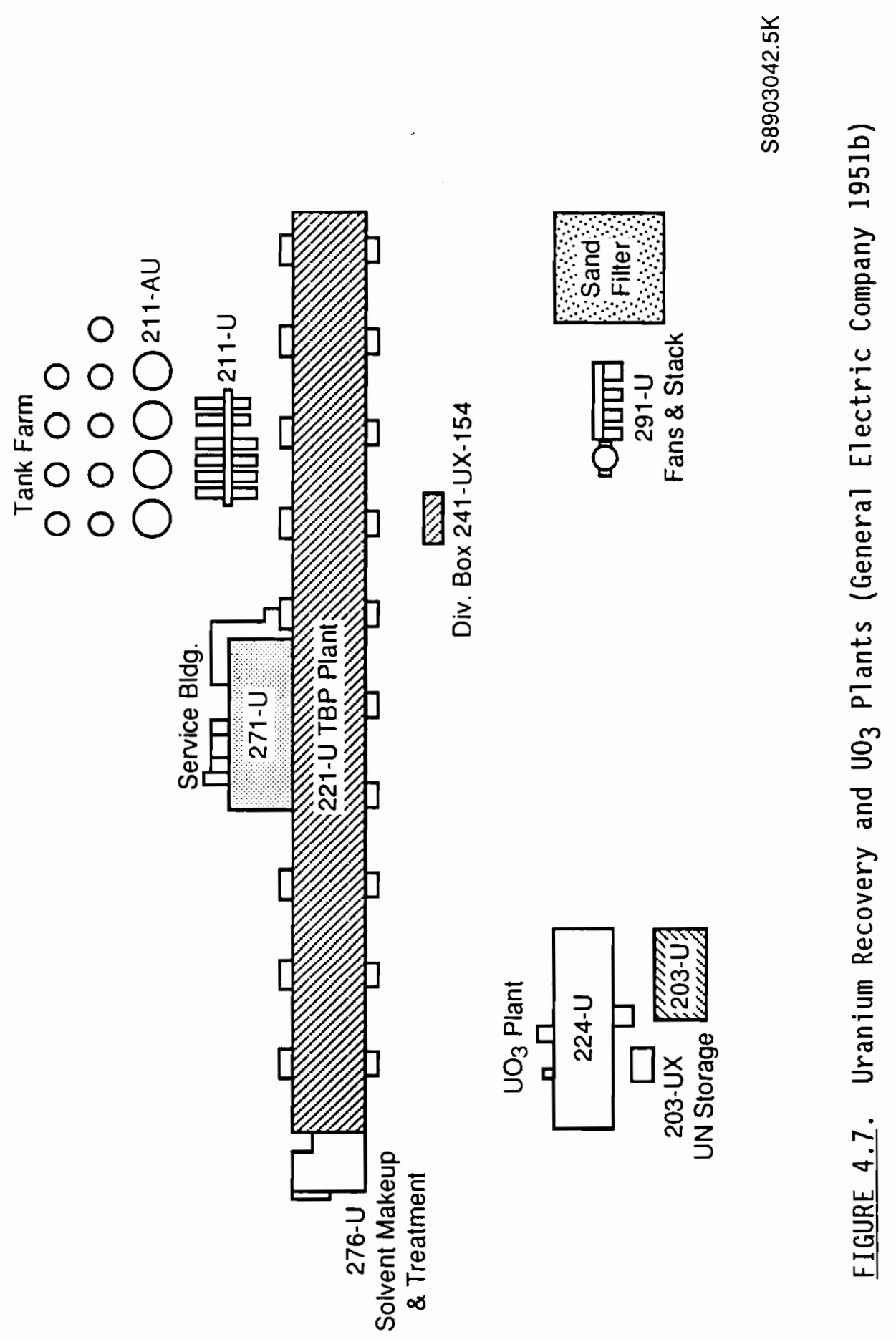


Summer $/ 54$ Process equipment changes to REDOX to reduce $\mathrm{Ru}$ emissions (Roberts 1958).

8/54 Off gases now routed through sand filter in REDOX after improved scrubbing or prefiltering. Oxidizer off gas routed through two caustic scrubbers in series, a fiberglass filter, and the sand filter before stack discharge.

1956 C Plant shutdown

1/56 PUREX startup

8/56 T Plant shutdown

1/58 U Plant shutdown

1962 C Plant restarted as pilot plant for recovery of $\mathrm{CS}$ and $\mathrm{Sr}$ from fission product waste.

12/66 REDOX shutdown

1967 C P1ant retired

6/72 PUREX shutdown

11/83 PUREX restart.

\subsection{EFFLUENTS}

Wastes from the separations processes fall into five categories: highactivity aqueous, low-activity aqueous, non-aqueous liquid, solids, and gases. The very small amount of non-aqueous liquid waste was usually disposed via trenching and backfilling. Solid wastes consisted mostly of decontamination rags, papers, and failed equipment pieces that were boxed and buried. Disposal of aqueous and gaseous wastes was handled on a routine basis, as discussed next.

\subsubsection{Gaseous Waste}

Gaseous waste is grouped into three headings: dissolver off-gases, process vesset vent systems, and exhaust ventilation air. Dissolver off-gases contained the major portion of the radioactive iodine (primarily ${ }^{131} \mathrm{I}$ ), as well as krypton and xenon isotopes. Dissolver off-gases also carried a high 
concentration of nitrogen oxides resulting from the reduction of nitric acid during the dissolution of the metal.

Meteorological conditions were considered in scheduling dissolution times; dissolution was timed so that the dissolver off-gases were sent out the stack during periods of maximum dilution. Dissolving was not permitted unless the dilution of gases from the top of the stack to the ground was expected to be a factor of 500 or more.

Water scrubbers were installed in B and T Plants in 1948 to reduce radioactive iodine concentrations in radioactive particles from the dissolver emissions. Sand filters were installed the same year to filter stack gases. Fiberglass filters were used a few years later to improve filtration efficiency for particles.

In 1950, silver reactors were installed to further reduce ${ }^{131}$ I emissions. The dissolver gases were heated to 200 to $230^{\circ} \mathrm{C}$ and passed over a ceramic packing coated with fused silver nitrate. The iodine was removed by the formation of silver iodide on the ceramic packing. The hot gases were then filtered through a fine fiberglass mat. Decontamination factors of 1000 for iodine emissions were routinely achieved when the silver reactors were working well. However, unexpected breakthrough of iodine occurred occasionally, and a backup system was installed that recovered nitric acid from the deiodized and filtered off-gases and then scrubbed the remaining gases with a sodium hydroxide solution. The gases were discharged into the ventilation exhaust stack following treatment.

Vessel vent gases consisted primarily of air or nitrogen used as a purge gas for instruments. After 1950, these gases were filtered through a fiberglass bed and discharged to the exhaust ventilation stack by means of a steam jet ejector.

Ventilation was used in the separations plants as a secondary method of preventing contamination spread (containment was the primary method). By controlling differential pressures between plant zones, air flow took place from less- toward more-contaminated zones. In large, unsubdivided zones, such as the crane working space above the canyon deck, eddies sometimes developed, upsetting this design intention. As shown in previous Figure 4.3, 
air flowed from the cabway to the cells, into the ventilation tunnel, and out the stack. Sand filters were installed for the existing processing facilities in 1948 ( $B$ and $T$ plants). Fiberglass filters were installed in 1950 in both $B$ and $T$ plants.

\subsubsection{Aqueous Waste}

Liquids leaving the separation building canyons were presumed to be radioactively contaminated, including condenser cooling water and heating steam condensate, as wel1 as process condensate and other wastes thought to have low activity. Most of the cooling water and steam condensate were impounded in a surface swamp or lake and allowed to seep into the deep sand bed that makes up the plateau on which the 200 Areas are located (Ruppert 1953). However, contamination appeared in some streams, which were then diverted to underground gravel pits called caverns. Figure 4.8 shows the typical ground disposal facilities.

Process condensates and other slightly contaminated streams were discharged to a crib, a buried structure filled with aggregate. The solution seeped into the sand bottom of the crib, which acted as a sorbent for many of the fission products.

High-level wastes were neutralized and stored in large underground tanks. Two types of tanks were used at Hanford: single-shell and double-shell. The single-shell tanks are reinforced concrete with carbon steel liners on the bottoms and sides. The 149 single-shell tanks, ranging in capacity from 210 to $3800 \mathrm{~m}^{3}$, were constructed between 1944 and 1964 (U.S. Department of Energy 1987).

Double-shel1 tanks range in size from 3800 to $4300 \mathrm{~m}^{3}$ and contain an inner steel liner in addition to an outer steel liner and concrete shell. Twenty of these tanks were constructed between 1970 and 1982 .

Each tank has a dome with risers and manholes. The solutions boil in the tanks, concentrating themselves. Vapors pass out of the tanks through a large, carbon-steel pipe manifold system to a tank used as a settling chamber, then to water-cooled condensers. The decontamination factors from tank to condensers was as high as $10^{8}$. Thus, the condensate could be cribbed. 


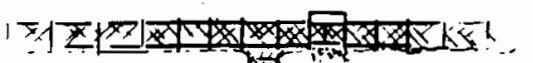
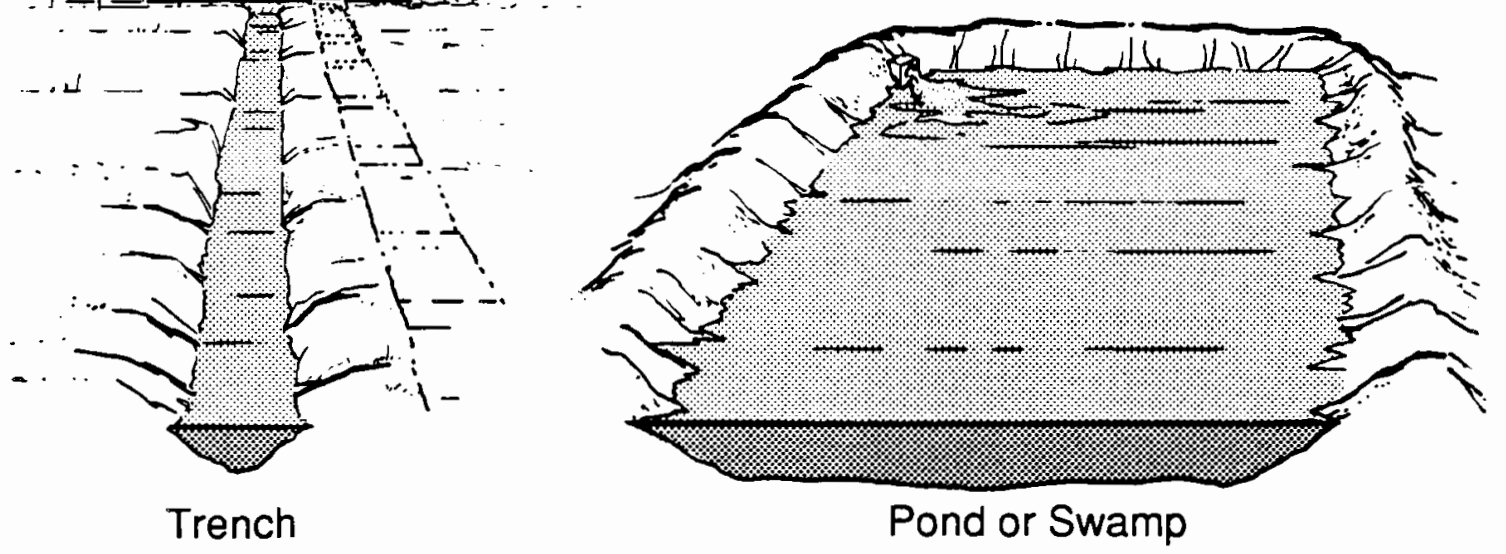

3 in. Macadam

$1 \mathrm{ft}$ Crushed Rock

$2 \mathrm{ft}$ Gravel 1-3 in.

$7 \mathrm{ft}$ Gravel >3 in.
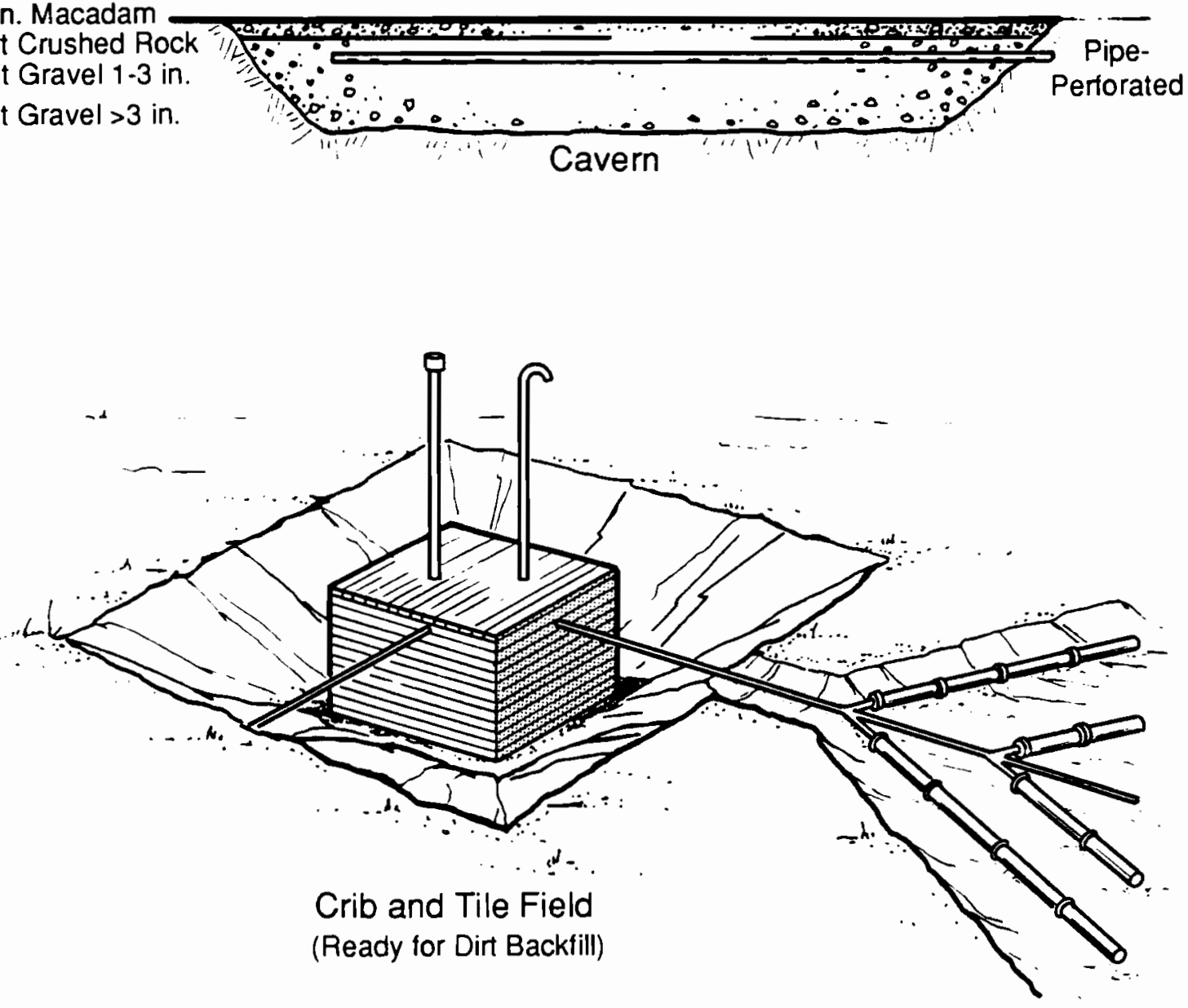

FIGURE 4.8. Typical Ground Disposal Facilities (Brown et al. 1956) 
Liquid wastes from the Isolation and Concentration Buildings were originally discharged into dry wells from which the solutions drained into the gravel soil. The wells were not in operation very long before they plugged up and were abandoned, and underground cribs were installed and used. 


\subsection{PLUTONIUM FINISHING}

The plutonium recovery and finishing operation facility, or Z Plant, began operations in late 1949 to process plutonium and prepare plutonium products. Before 1949, all plutonium nitrate solutions had been shipped offsite for further processing. The process description was obtained from Hanthorn (1957).

\subsection{PROCESS DESCRIPTION}

Plutonium was brought into $Z$ Plant as a liquid nitrate solution. The plutonium was precipitated as the oxalate, converted to the fluoride, and reacted at high temperature with metallic calcium, forming the metal. The slag and crucible were routed to a plutonium recovery process; in later years, the buttons were remelted and cast into the finished shape. Certain finishing operations were performed: the shape was coated with nickel and polished, enabling it to be handled without spreading plutonium contamination. Up to this point, all of the plutonium operations were conducted in tightly sealed enclosures.

At startup, the finishing operations were very labor intensive. After 1953, much of the process was automated to reduce worker exposure. Plutonium recovery operations started in 1955 at the Recuplex facility (see Section 5.2).

\subsection{FACILITY DESCRIPTION}

The $Z \mathrm{Pl}$ ant is located in the 200 West Area as shown in Figure 5.1. The primary processing facility, 234-5Z, is a large (more than 200,000 $\mathrm{ft}^{2}$ ), concrete, multistory structure. The building has a substantial processing area and vault, analytical and development laboratories, shops, and miscellaneous services.

Next to the main building are the Americium Recovery (242-Z) and Recuplex/Plutonium Reclamation Facility (236-Z) operations. 242-Z is connected to 234-5Z with a corridor and shares the 234-5Z Building ventilation 


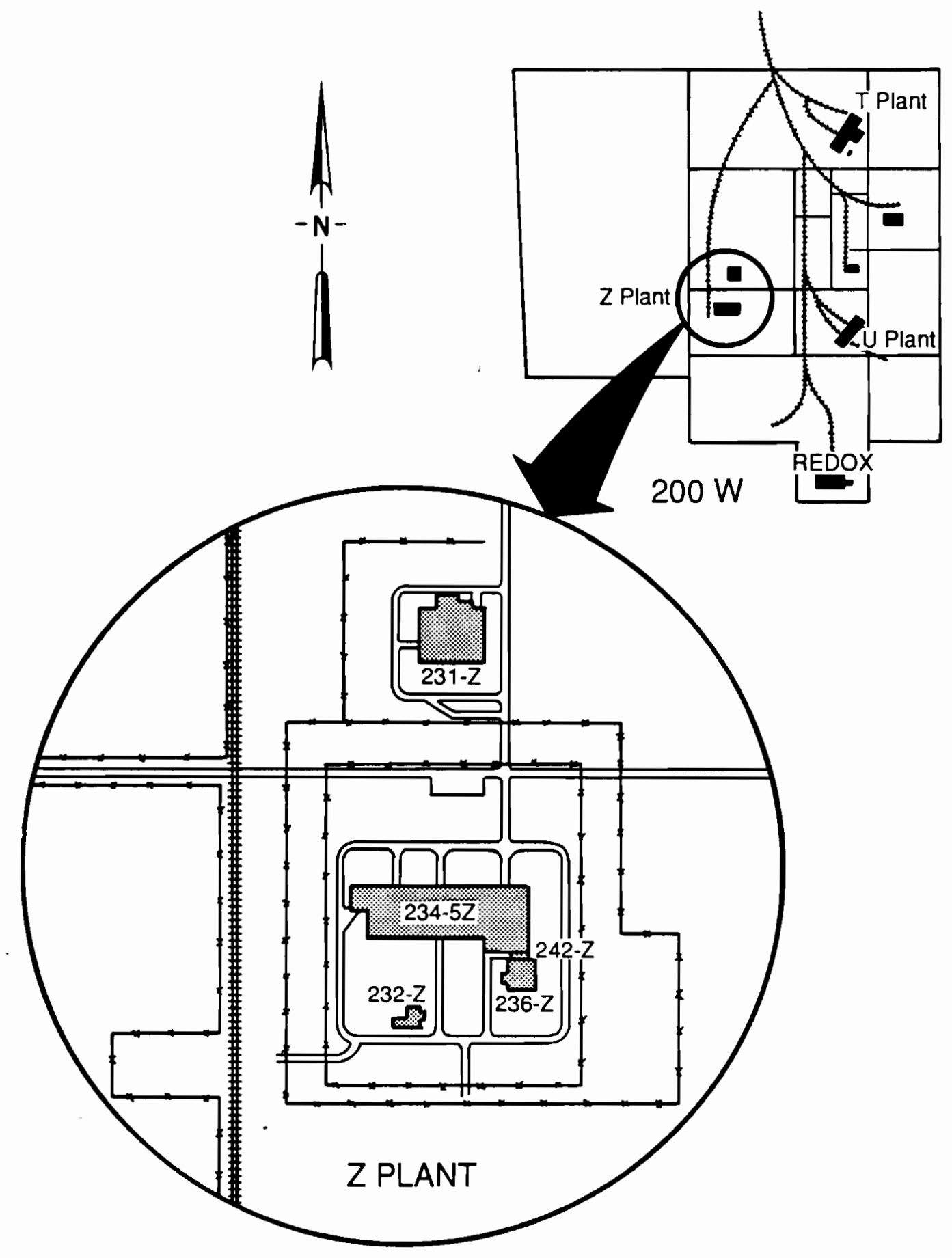

FIGURE 5.1. Location of Plutonium Finishing Operations 
system. $236-Z$ is a four-story structure of reinforced concrete and contains a process cell with 2-ft-thick concrete walls.

The large building north of 234-5Z (see Figure 5.1) is a plutonium metallurgy facility containing laboratories and metallurgical equipment for research on plutonium and alloys. The two-story concrete building has an air-handling system on the second floor.

An incinerator and leach facility $(232-Z)$ is slightly south of the 234-5Z building. The concrete-block structure is divided into four areas: process area, chemical room, first-floor building services, and second-floor ventilation equipment. A glove box incinerator in the process area is used to incinerate dry wastes from which radioactive materials are then recovered.

\subsection{IIMETABLE}

Key operations at $\mathrm{Z} \mathrm{Pl}$ ant are identified here (Rockwell Hanford Operations 1987).

1949 Startup of plutonium finishing in 234-5Z Building.

1953 Original process automated to reduce worker radiation exposure.

1955 Startup of Recuplex (236-Z), recovery of plutonium from finishing plant liquid waste.

1961 Startup of incinerator and leach facilities (232-Z) to recover plutonium from solid waste.

1962 Criticality accident in Recuplex; facility shutdown.

1964 Startup of Plutonium Reclamation Facility to replace Recuplex.

1965 Americium recovery starts in 242-Z.

1971 Startup of plutonium oxide blending and production in 234-5Z.

1973 Incinerator and leach facilities shutdown.

1976 Americium ion exchange explosion. Americium recovery shutdown. 234-5Z shutdown. 
1978 Restart of 234-5Z operations.

1979 High stack release. Plutonium reclamation facility shutdown. Plutonium metal and oxide production ends.

1984 Plutonium Reclamation Facility started up.

1985 Plutonium Reclamation Facility shutdown.

1987 Plutonium metal line started up.

\subsection{EFFLUENTS}

Liquid waste from Z Plant contains only minor amounts of fission products. However, it does contain low concentrations of plutonium and other transuranic (TRU) elements, and is high in metallic nitrates. Initially, this waste was discharged via cribs to soil columns, which sorbed the TRU elements and kept them close to the point of discharge. Later, waste from Z Plant was stored in underground tanks (U.S. Department of Energy 1987). 


\subsection{RESEARCH AND DEVELOPMENT}

During the early years of Hanford Site operations (1944 to 1949), all research and development (R\&D) work at Hanford was in support of plutonium production. The principal R\&D activity was the cold semiworks activities in the 321 Building, where pilot-plant scale work was conducted for the REDOX $\mathrm{P} 7$ ant and, later, the PUREX Plant. Because the radioactive contamination in this facility was limited to uranium, which represented a much smaller radiation hazard than plutonium, radiation dose rates were low and REDOX and PUREX operating personnel were trained here.

Studies to investigate the effect of radioactive contamination on biological species began when Hanford Site operations began, starting with the construction of fish-rearing ponds and sheep pens at 100-F Area. Even the environmental monitoring that began at that time could be considered R\&D, because there was so little precedent for that activity.

In the 1950s, facilities in the 300 Area were greatly expanded, including construction of the Plutonium Fuels Pilot Plant (PFPP) and the Plutonium Recycle Test Reactor (PRTR), where work was directed toward developing peaceful uses for plutonium. Another significant R\&D activity begun in the early 1960 s was development of the waste vitrification process for stabilizing radioactive waste in glass or glass-like materials.

Facilities constructed in the 1950s also included the Radiometallurgy Laboratory and the High-Level Radiochemistry Laboratory, whose functions were described by their names.

R\&D activities conducted in the reactor areas (100 Area) included special irradiation of various materials in the reactors, largely irradiation of target materials containing lithium for tritium production and irradiation of thorium to produce $233 \mathrm{U}$. Because an individual reactor required more treated water than many cities and towns do, the water treatment process was studied extensively, and unique improvements in water treatment were achieved. In 
addition to reactor-associated activities, tritium extraction facilities were operated at the 108B Building before construction of the Savannah River Project.

R\&D activities conducted in the separations areas (200 Areas) were production related. For example, the hot semiworks at 201-C Building in the 200 East Area supported REDOX and PUREX operations. These facilities were al so used to study the separation of strontium and cesium from tanked waste. Thorium was processed through the PUREX Plant on a special campaign, and the $233 \mathrm{U}$ recovered was concentrated at 231-Z Building.

The Fast Flux Test Facility (FFTF) is a sodium-cooled reactor located in the 400 Area about 6 miles northwest of the 300 Area. The reactor achieved initial criticality on February 9, 1980, and fu11 power (400 MW) on December 21, 1980. This reactor was designed to be a "zero-release" facility. In fact, releases of radioactive materials have been 1 imited to a few curies of argon- 40 .

Because the FFTF is sodium cooled, an exceptionally high degree of c001ant containment must be maintained. At operating temperatures the molten sodium would burn if exposed to air. The reactor is equipped with primary and secondary sodium-coolant loops. The secondary coolant loops dump their heat to the atmosphere in large air-cooled heat exchangers. Because the reactor is sodium cooled and because sodium reacts with water, there are no radioactive liquid effluents. The small amount of contaminated water generated in decontamination and other activities that use water is transported to the 200 Areas for treatment and disposal, as is the solid radioactive waste.

The radioactive wastes from R\&D activities were generally similar in radioactive components to wastes from production facilities and of a much smaller magnitude when compared with effluents from other Hanford Site operations.

\subsection{BUILDING (RADIOCHEMISTRY LABORATORY)}

Radiochemistry activities in the 300 Area began in 1944 in the 3706 Building, where work was 1 imited to low-level radioactivity handled in hoods. Chemistry performed included support for fuel fabrication and REDOX 
process development, which was occurring in the 321 Building. Radiochemistry activities increased greatly in 1953 with the completion of the 325 Radiochemistry Laboratory. Whereas only some hoods in the 3706 Building had High Efficiency Particulate Air (HEPA) filters, all hoods in the 325 Building did. In addition, radioactive liquid waste collection and handling facilities were provided. Liquid radioactive wastes from centralized facilities were transported to the 200 Areas for disposal. The addition of the High-Level Radiochemistry Laboratory to the 325 Building provided shielded cells and enabled a significant increase in the amounts of radioactive materials that could be safely handled.

Radiochemistry performed in these cells included radionuclide separation and concentration for special programs, which included promethium-147, plutonium-238, plutonium-239, cesium-137, and strontium-90. Radiochemistry was also performed in support of the solidification of high-level radioactive liquid waste. That effort, which was primarily conducted in the 324 Building, is discussed in Section 6.4.

\subsection{BUILDING (RADIOMETALLURGY LABORATORY)}

The 327 Radiometallurgy Laboratory was built in 1953 and provided shielded cells for the destructive examination of irradiated materials including fuels. Effluent gases were passed through HEPA filters, and in 1960, charcoal absorbers were added for the collection of iodine-131. Liquid radioactive waste was discharged to the central collection system for transport to the 200 Areas for disposal. Activities in the 12 shielded cells were standard for metallurgical examination except that sectioning, grinding, polishing, and microphotography were performed by manipulators and other remote-handling devices.

\subsection{8/309 BUILDINGS (PLUTONIUM FUELS PILOT PLANT AND PLUTONIUM RECYCLE TEST REACTOR)}

The PFPP (308 Building) and the PRTR (309 Building) were first used in 1960. The initial fuel fabrication programs in the 308 Building were directed to the development of fuels used in the PRTR. Operations later 
evolved to developing plutonium fuels of many kinds, including these for the Liquid Metals Fast Breeder Reactor (LMFBR) program, which included the FFTF. The plutonium fuel fabrication program has always been conducted in facilities with extensive emission controls on exhaust air, which must pass through two sets of HEPA filters in series. These operations did not generate radioactive liquid wastes; solid wastes were transported to the 200 Areas for disposal from the beginning of operations.

The PRTR, a heavy-water-cooled, heavy-water-moderated reactor, began operating in November 1960 and reached full power of 70 MW in July 1961. Heavy water is composed of normal oxygen combined with hydrogen containing a proton and a neutron in the nucleus of the atom instead of merely a proton. This heavy hydrogen occurs naturally and is not radioactive.

The reactor consisted of vertical fuel channels in a tank that contained the moderator. The reactor power level was controlled by raising and lowering the liquid level of the moderator in this tank. The reactor was shut down by opening a "dump" valve that allowed the moderator to drop into a tank below. The reactor coolant passed through the reactor and through a heat exchanger that had treated river water on the secondary side. The secondary coolant circulated through a dump heat exchanger, and the heat was discharged to the Columbia River. Normal effluents contained little or no radioactivity. The City of Richland water treatment facility was put in service in 1963 four miles downstream from this discharge point. Before 1963, Richland obtained water from wells recharged by water from the Yakima River. Air from the reactor building was discharged through HEPA filters.

\subsection{BUILDING (CHEMICAL AND MATERIALS ENGINEERING LABORATORY)}

The Chemical and Materials Engineering Laboratory (324 Building), first occupied in 1966, consists of two groups of large shielded cells. The chemistry cells consist of four cells connected to an air lock where studies of various processes for solidifying high-level radioactive wastes were conducted. Megacurie quantities of radioactive waste were brought into the facility in spherical shielded casks. These wastes were converted to solid, glass-like or ceramic material in several tests. Waste gases were exhausted 
through two sets of HEPA filters in series, and liquid radioactive wastes were either discharged to central handling facilities for 200 Area disposal or returned to the 200 Areas in the spherical shielded casks.

\subsection{CRITICAL MASS LABORATORIES}

Critical mass laboratories were operated first at the 120 Building near $100-F$ Area and later at the 209-E Building in the 200 East Area. These 1aboratories were nuclear physics facilities where the physics of plutonium solutions and solids were studied to avoid accidentally creating a criticality in operating facilities (Kreusi 1949, 1950). The first facility began operating in the 120 Building in April 1950. In November 1951, one of the experiments with a plutonium solution resulted in widespread contamination in the laboratory (Riggs 1951). Cleanup involved the use of nitric acid, and on December 4, 1951, some rags soaked in nitric acid spontaneously ignited (Riggs 1951). The fire did not destroy the metal building, but equipment was so badly contaminated that the facility was closed down. All detectable plutonium and plutonium-contaminated materials have since been removed from the site.

The 209E Critical Mass Laboratory began operating in July 1961. The building, located in the central 200 East Area, contained a critical assembly room with a minimum wall thickness of $3 \mathrm{ft}$, a mixing room with glove boxes and a mixing hood, and a control room from which experiments could be remotely conducted.

\subsection{IRITIUM EXTRACTION FACILITIES $(P-10)$}

Tritium extraction operations were performed intermittently between August 1949 and 1955 in the P-10 Plant. Initially, target elements containing lithium fluoride were irradiated, but these were soon replaced by an aluminum/lithium alloy. Both types of target material were enclosed in aluminum jackets. Tritium is a hydrogen atom that contains one proton and two neutrons in the nucleus as compared to only a proton in ordinary hydrogen. 
Tritium is produced by exposing lithium- 6 to a neutron flux in a reactor. Some of the lithium atoms capture a neutron, become unstable, and split into tritium and helium.

Effluents from this process were disposed of in the $100-B$ and $C$ areas, where the P-10 Plant was located. Most effluent contamination was in solid form, which was buried in local burial grounds, and tritium gases, which escaped through a $300-\mathrm{ft}$ stack. The small amount of liquid waste generated was sent to a local crib. Because tritium production is an activation rather than a fission process, no fission products were generated. The primary radioactive contaminant from the process was tritium. 


\subsection{TANK FARMS AND WASTE RECOVERY}

This chapter describes high-level liquid waste operations since 1944. High-level 1iquid waste from the separations processes in the 200 Areas was neutralized and piped to large tanks, several of which composed a tank farm. Initially, uranium was included in this high-level waste because it was not separated during the bismuth phosphate process. In 1952 the uranium recovery operation was begun to retrieve the uranium from the waste. 0ther operations influencing tank contents are described below (U.S. Department of Energy 1987):

- in-tank scavenging of strontium and cesium by the precipitation of strontium phosphate and cesium ferrocyanide to reduce the concentration of $90 \mathrm{Sr}$ and ${ }^{137} \mathrm{Cs}$ in supernatant liquids, and disposal of the supernatant liquids as low-level waste

- removal of ${ }^{90} \mathrm{Sr}$ and ${ }^{137} \mathrm{Cs}$ at $\mathrm{B}$ Plant to reduce in-tank heat generation and allow concentration of the remaining waste

- concentration of tank contents by evaporation of water to crystallize the waste as a salt cake.

\subsection{TANK FARMS}

The first tanks built to hold high-level liquid waste were constructed in groups, each tank having a capacity from 500,000 to 1,000,000 gallons, with an internal diameter of approximately $75 \mathrm{ft}$, and a height from 20 to $40 \mathrm{ft}$ (Pilkey et a1. 1958). A schematic diagram of a tank is shown in Figure 7.1. A continuous steel liner covers the bottom and sides of the reinforced-concrete tank. The first 12 tank farms contained a total of 149 such tanks known as single-shell tanks. Tanks were buried so that the top of the domed tank is several feet underground.

Several nozzles enter the tank through the dome to provide a means for temperature, pressure, liquid-level, and radiation measurement (Anderson and Rohrmann 1956).

Wastes from the separations plants are routed to the tank farms through underground stainless steel pipes to a diversion box. The pipes are encased 

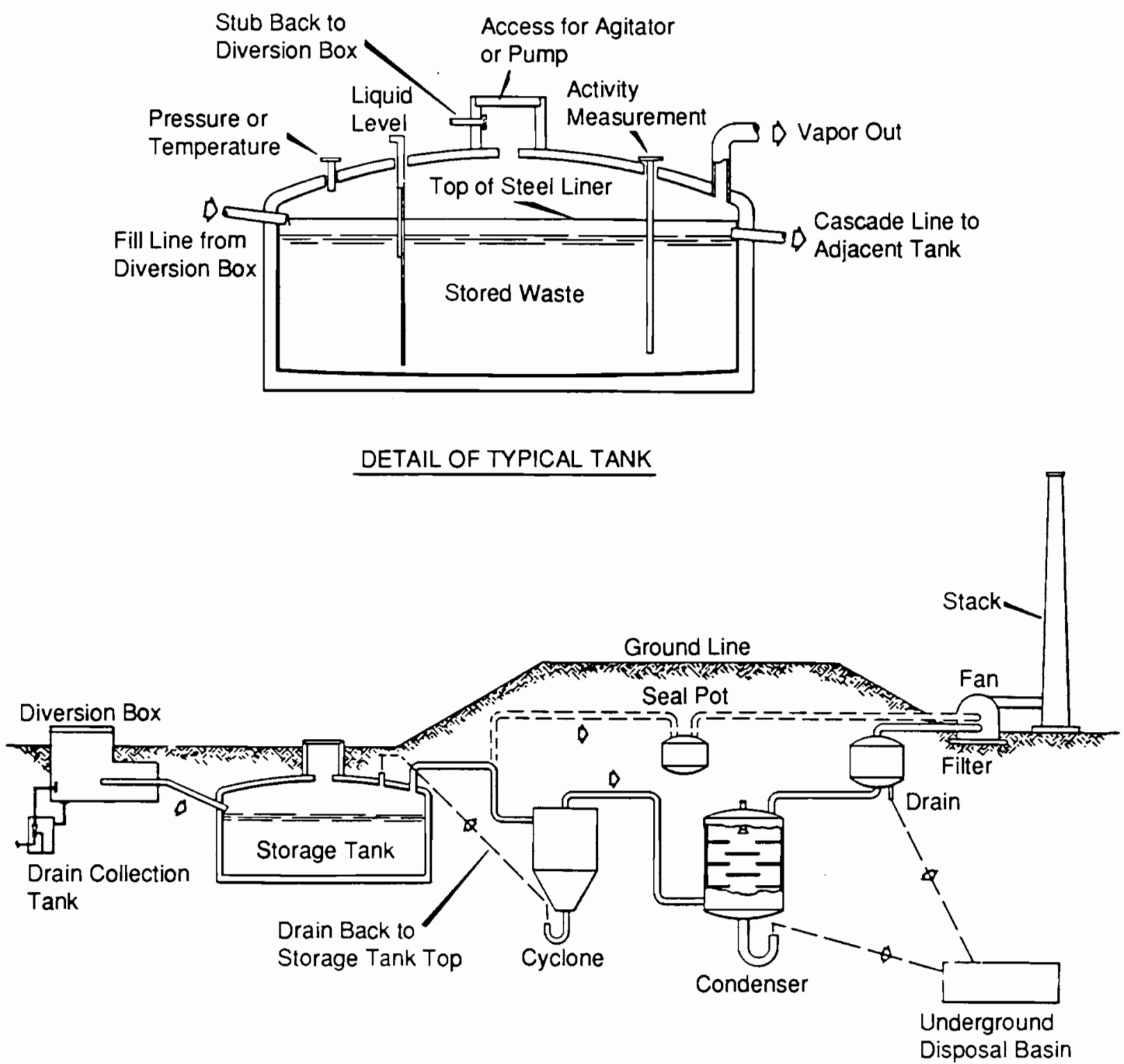

\section{SCHEMATIC ELEVATION VIEW}

FIGURE 7.1. Typical High-Level Waste Storage Facility (Anderson and Rohrmann 1956)

in concrete troughs, and the diversion box is also of thick concrete construction. From the diversion box, wastes can be directed to individual tanks. The bismuth phosphate separations process used in B and T Plants generated large amounts of dilute waste in comparison with the REDOX and PUREX processes. Although the bismuth phosphate wastes generated considerable radioactive decay heat, they were so dilute that the liquid did not 
boil. All tanks were equipped with off-gas treatment as shown in Figure 7.1. Radioactive materials that may have vaporized during the heating process were returned to the tank. Water was returned for temperature control or removed for volume reduction. Bismuth phosphate wastes were later extracted from the tanks and fed to a uranium recovery process (see Section 4.2.5).

Wastes from REDOX and PUREX, however, were more concentrated. Waste tanks equipped to handle boiling wastes had air-lift circulators to keep the contents well mixed. These tanks also had facilities to remove condensate, entrained liquid, and particles from the air before discharging it to the atmosphere. Water from reflux condensers was returned to the tank for temperature control.

Concrete tanks with two carbon-steel liners with an annulus between the liners for secondary containment and leak detection were later built. These double-she 11 tanks were $75 \mathrm{ft}$ in diameter and had a capacity of 1 million gallons. The tanks had improved leak detection devices.

\subsection{WASTE RECOVERY}

The radionuclides ${ }^{90} \mathrm{Sr}$ and ${ }^{137} \mathrm{Cs}$ and their decay products are the major sources of heat in Hanford high-level waste after about 5 years' decay. Some of the strontium and cesium fission products were removed from the waste and separately isolated to reduce the heat generation and corrosion rate in the tanks. B Plant, described in Chapter 4.0, was modified in 1968 to permit removal of these fission products by a combination of precipitation, solvent extraction, and ion exchange steps (U.S. Department of Energy 1987).

Cesium was primarily in the supernatant liquid in the tanks and strontium was mostly in the sludge. To extract the components, the supernatant was pumped out and the sludge was converted to slurry with special high-pressure nozzles using water or supernatant. This slurry was piped to holding tanks and allowed to separate.

Cesium from the supernatant from the original tanks and the holding tanks was converted to cesium chloride with concentrated hydrochloric acid. Recovery of cesium was $88 \%$ using this method. To recover strontium, sludge from the holding tank was dissolved in acid; strontium was separated by 
solvent extraction and subsequently precipitated by the addition of sodium fluoride at high $\mathrm{pH}$. Eighty-five percent of the strontium was recovered.

In 1974, the Waste Encapsulation and Storage Facility converted solutions of strontium and cesium nitrates recovered at B Plant to strontium fluoride and cesium chloride solids that are doubly encapsulated in metal and stored in a water basin. Although these materials have potential beneficial use as heat and/or irradiation sources, they have not yet been developed for commercial use. 


\subsection{REFERENCES}

Anderson, C. R., and C. A. Rohrmann. 1956. "The Design and Operation of High Level Waste Storage Facilities." In Proceedings of the International Conference on the Peaceful Uses of Atomic Energy, Volume 9: Reactor Technology and Chemical Processing. United Nations, New York, pp. 640-647.

Anderson, J. D. 1974. Emitted and Decayed Values of Radionuclides in Gaseous Wastes Discharged to the Atmosphere from the Separations Facilities Through Calendar Year 1972. ARH-3026, Atlantic Richfield Hanford Company, Richland, Washington.

Brown, R. E., H. M. Parker, and J. M. Smith. 1956. "Disposal of Liquid Wastes to the Ground." In Proceedings of the International Conference on the Peaceful Uses of Atomic Energy, Volume 9: Reactor Technology and Chemical Processing. United Nations, New York, pp. 669-675.

DeNea1, D. L. 1965. Historical Events - Reactors and Fuel Fabrication. RL-REA-2247, Hanford Site, Richland, Washington.

7 Evans, T. F., and R. E. Toml inson. 1954. Hot Semiworks Redox Studies. HW-31767, Hanford Atomic Products Operation, Richland, Washington.

6 E. I. du Pont de Nemours and Company. 1944. Hanford Technical Manual Section C - Separations. HW-10475C-DEL, Hanford Works, Richland, Washington.

Geier, R. G. 1966. Summary of Reactor Effluent Research and Development Program. DUN-1664-DEL, Douglas United Nuclear, Incorporated, Richland, Washington.

General Electric Company. 195la. REDOX Technical Manual. HW-18700 DEL, Hanford Atomic Products Operation, Richland, Washington.

General Electric Company. 1951b. Uranium Recovery Technical Manual. HW-19140 DEL, Hanford Atomic Products Operation, Richland, Washington.

General Electric Company. 1955. PUREX Technical Manual. HW-31000-DEL, Hanford Atomic Products Operation, Richland, Washington.

Genera1 Electric Company. 1963. Hazards Summary Report. Vol.3 Description of 100-B, 100-C, 100-D, 100-DR, 100-F, and 100-H Production Reactors. HW-74094, Hanford Atomic Products Operation, Richland, Washington.

Hanthorn, H. E. 1957. Hanford History, Technology, Expansion and Present Efforts. HW-51188, Hanford Atomic Products Operation, Richland, Washington. 
Kreusi, F. E. 1949. Outline of Proposed Experiments, P-11 Project. HW-14049, Hanford Atomic Products Operation, Richland, Washington.

Kreusi, F. E. 1950. Out1 ine of Proposed Experiments, P-11 Project, Supplement A. HW-17291, Hanford Atomic Products Operation, Richland, Washington.

13 Lockwood, E. H. 1958. IPD Pile Physics Primer, Chapter 3 - The Pile Structure. HW-51856-CH3, Hanford Atomic Products Operation, Richland, Washington.

- McCullugh, R. W., and J. R. Cartmell. 1968. Chronological Record of Significant Events in Chemical Separations 0perations. ARH-780, Atlantic Richfield Hanford Company, Richland, Washington.

14 Parker, H. M. 1947. H. I. Lecture Series, Part II. HW-7184, Hanford Works, Richland, Washington.

15 Pilkey, 0. H., A. M. Platt, and C. A. Rohrmann. 1958. "The Storage of High- Level Radioactive Wastes; Design and Operating Experience in the United States." In Proceedings of the Second United Nations International Conference on the Peaceful Uses of Atomic Energy, Volume 18: Waste Treatment and Environmental Aspects of Atomic Energy. United Nations, Geneva.

Riggs, L. R. 1951. P-11 Laboratory Fire Investigation, December 4, 1951. HW-22936, Hanford Atomic Products Operation, Richland, Washington.

18 Roberts, R. E. 1958. History of Airborne Contamination and Control 200 Areas. HW-55569 RD, Hanford Atomic Production Works, Richland, Washington.

16 - Rockwel1 Hanford Operations. 1987. Historical Timelines of Hanford Operations. RHO-HS-ST-10, Vol. I, Richland, Washington.

Ruppert, H. G. 1953. Unconfined Underground Radioactive Waste and Contamination in the 200 Areas, HW-28471, Hanford Atomic Products Operation, Richland, Washington.

Stenner, R. D., et al. 1988. Hazard Ranking System Evaluation of CERCLA Inactive Waste Sites at Hanford. PNL-6456, Pacific Northwest Laboratory, Richland, Washington.

United Nuclear Industries, Inc. 1978. N Reactor Updated Safety Analysis Report. UNI-M-90, Vol.1, Richland, Washington.

U.S. Department of Energy. 1987. Final Environmental Impact Statement Disposal of Hanford Defense High-Level, Transuranic and Tank Wastes. DOE/EIS-0113, Volume 2, Hanford Site, Richland, Washington. 


\subsection{GLOSSARY}

activation products

autoclave

billet

charge

cladding

clear wells

crib

criticality

decontamination factor

dummy charge

electron volt

erg

heel materials that become radioactive after exposure to a neutron flux

a vessel for sterilizing or cooking by superheated steam under pressure; to sterilize or cook by such a device

a smal1-circumference, unfinished bar of metal

the fissionable material or fuel placed in a reactor to produce a chain reaction; to install the charge in a reactor

a layer of metal or alloy bonded to another metal; the process of bonding such materials

reservoir of treated process water

buried structures (often wood or concrete) filled with aggregate that held or dispersed liquids and/or solutions for percolation into the ground

the point at which a nuclear chain reaction becomes self-sustaining

the factor by which the concentration of contaminants is reduced. Equal to radioactivity initially present divided by radioactivity present at step in question.

fuel elements not containing uranium placed into the front and rear face of the reactors to 1 imit exposure and to hold the uranium charge in the desired position in the reactor

a unit of energy equal to that attained by an electron falling unimpeded through a potential difference of one volt; $1.602 \times 10^{-12} \mathrm{erg}$

the unit of work done by one dyne (one $\mathrm{g} \mathrm{cm} / \mathrm{s}^{2}$ ) acting through a distance of one centimeter

undissolved uranium fuel remaining in the dissolver after the dissolution process is terminated 


$\begin{array}{ll}\text { isotope } & \begin{array}{l}\text { any of two or more forms of an element having the } \\ \text { same atomic number, but different atomic weights } \\ \text { or mass numbers }\end{array} \\ \text { jacket } & \text { thin metal covering over the uranium fuel } \\ \text { jet } & \text { method of solution transport in separations } \\ & \text { facilities } \\ \text { lugs } & \text { heavy nuts used with bolts as fasteners } \\ \text { metathesis } & \text { the interchange of elements or radicals between } \\ \text { compounds } & \text { million electron volts } \\ \text { MEV } & \text { measure of radiation absorption, one rep is equal } \\ \text { mrep } & \text { to the absorption of } 83 \text { ergs/g in air } \\ \text { neutron } & \text { one of the elementary particles of an atom; } \\ \text { neutrons are uncharged, have approximately the } & \text { same mass as protons, interact strongly with } \\ \text { nuclei, and are readily absorbed }\end{array}$




\section{APPENDIX}

SUMMARY OF TSP COMMENTS AND BATTELLE RESPONSES 


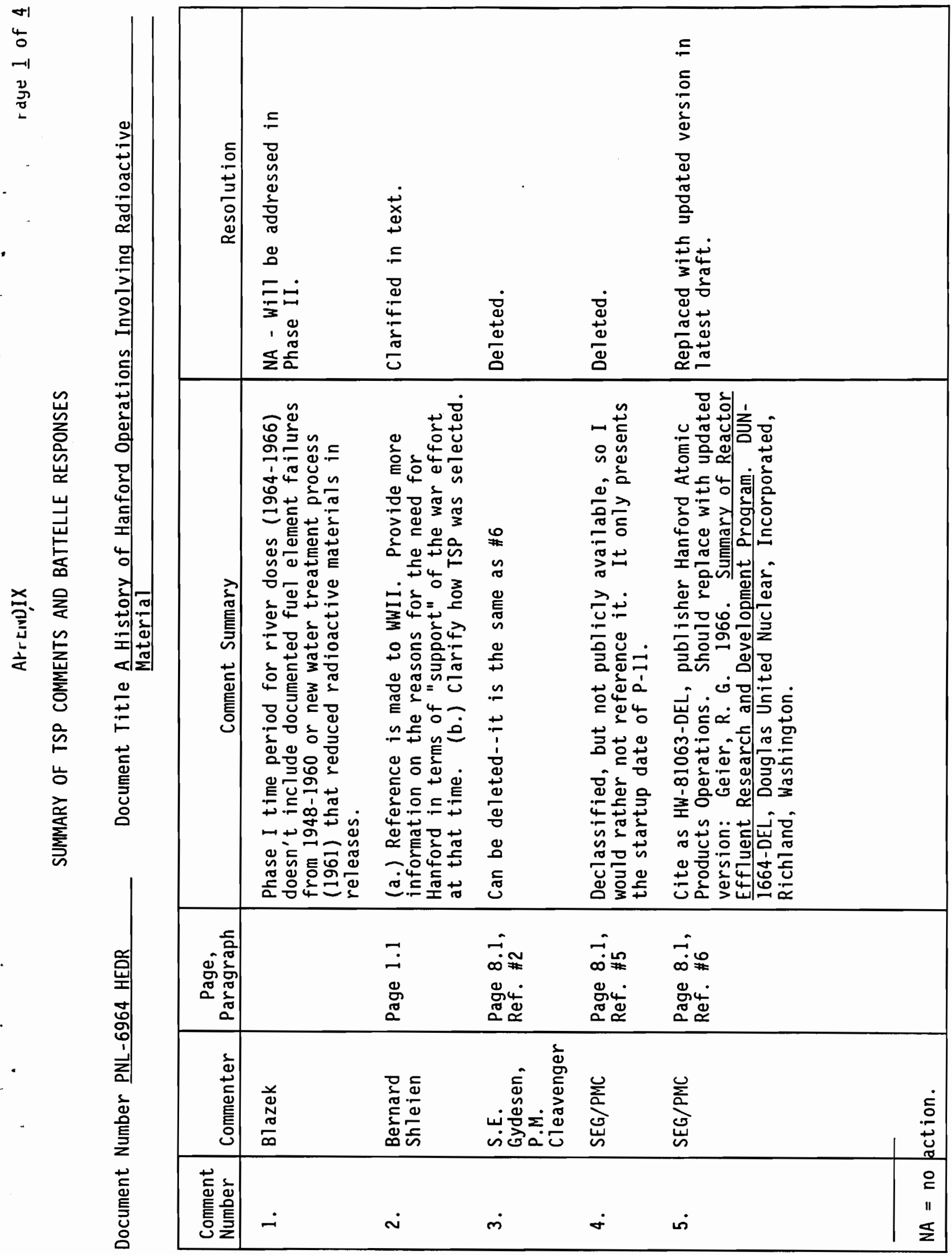




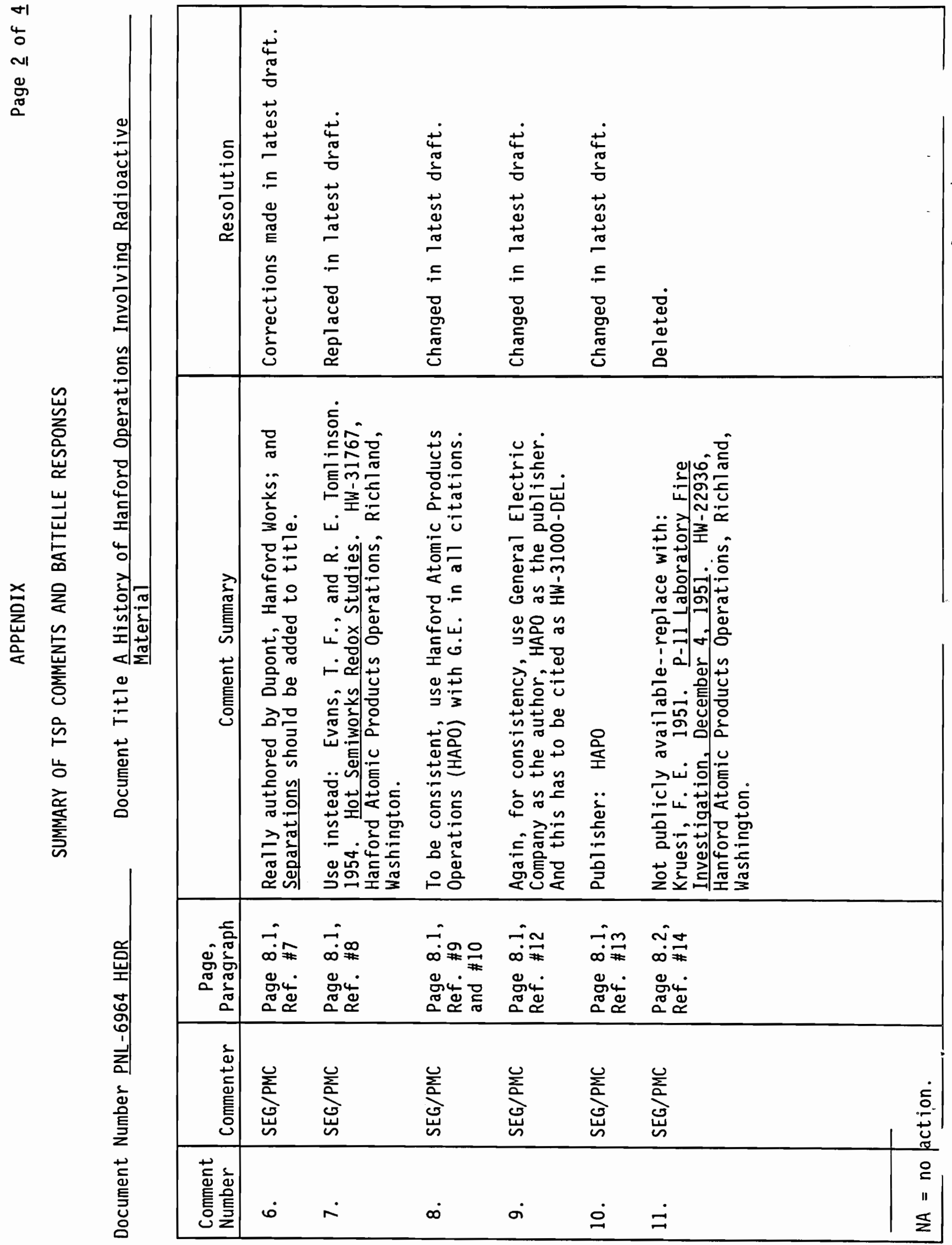




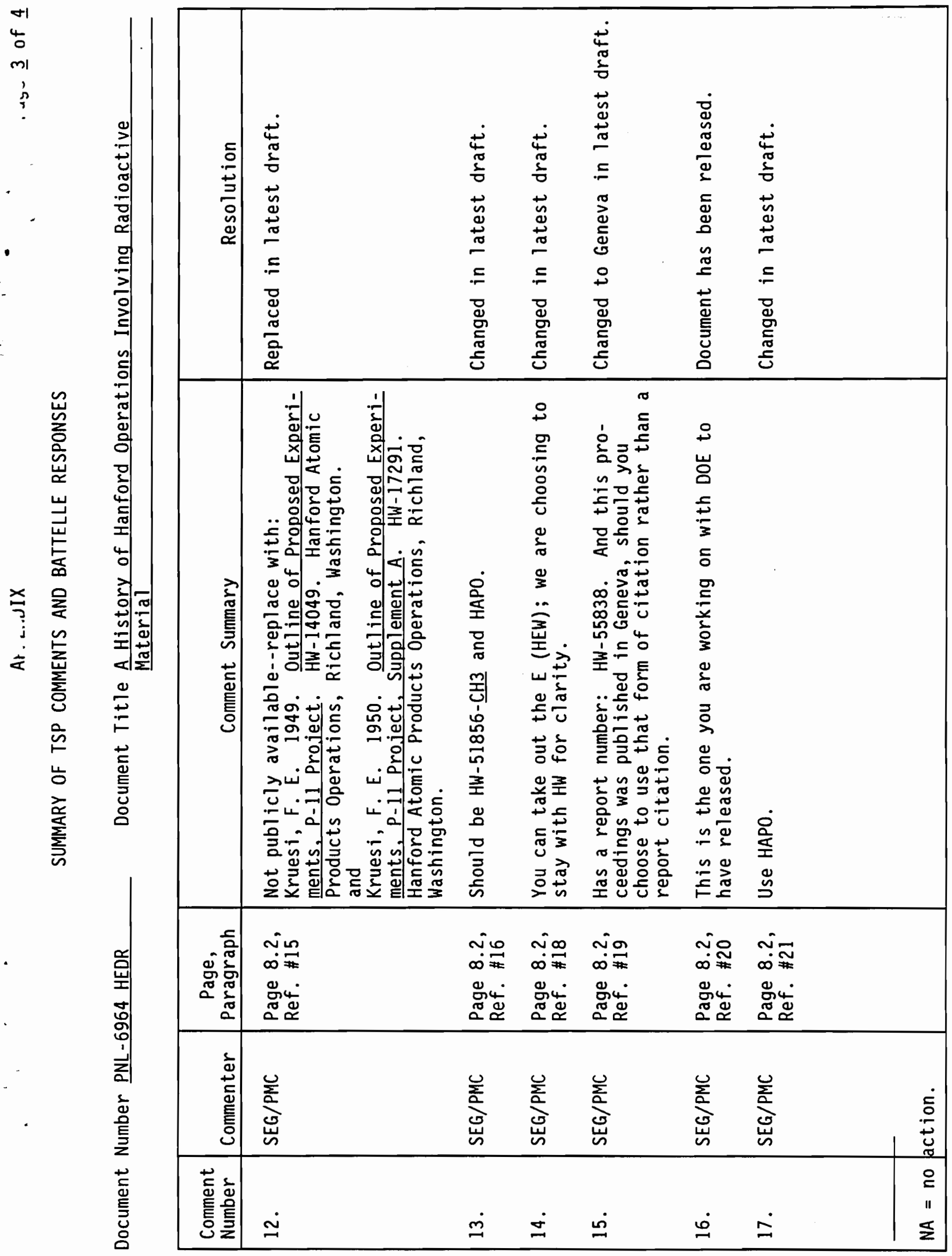




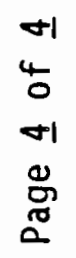
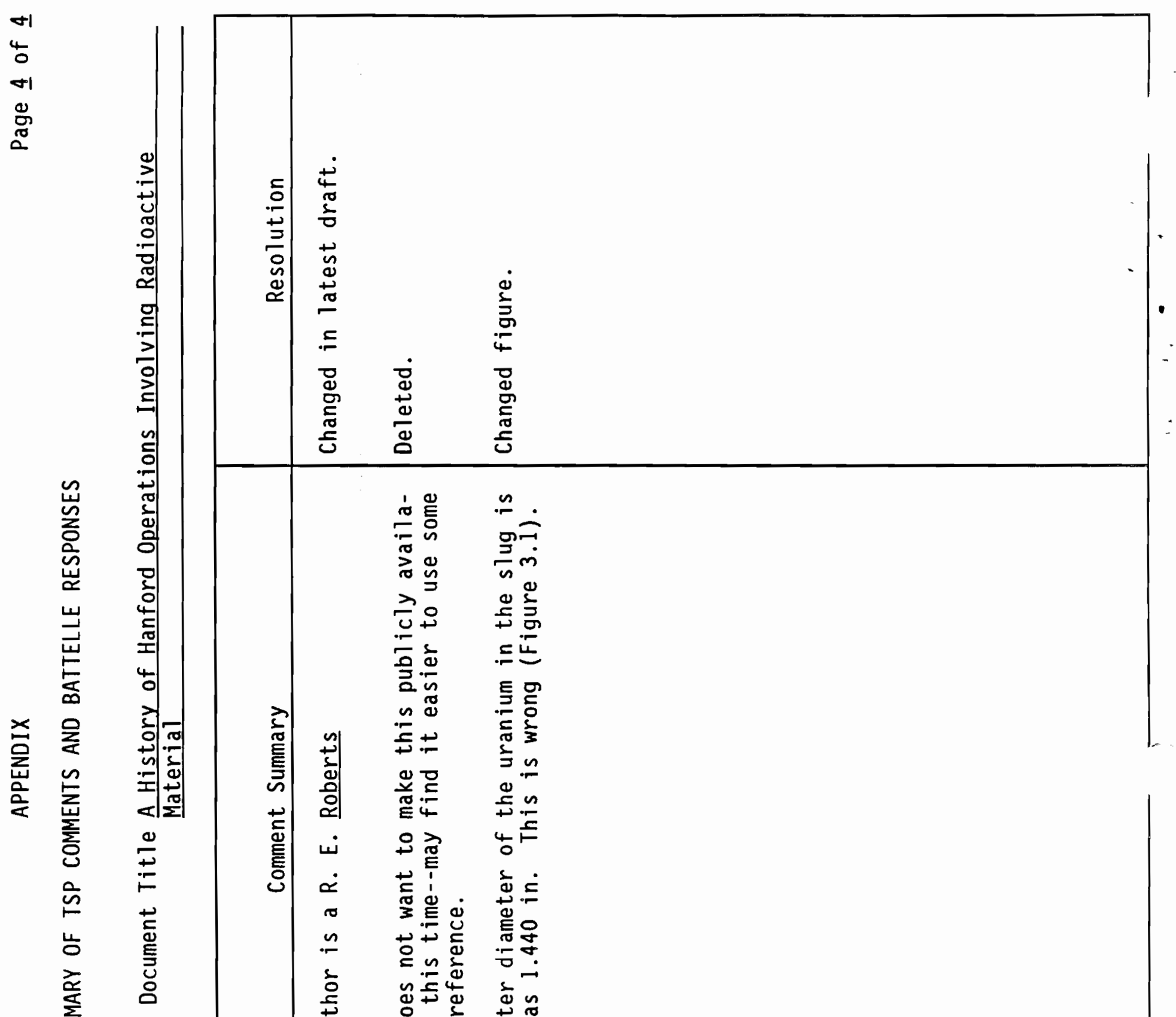

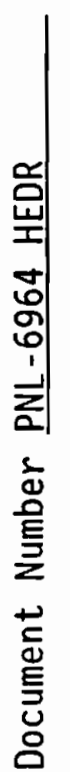

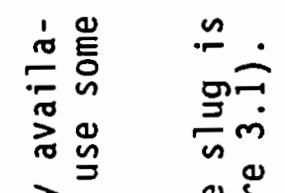

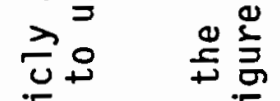

它告

艺的 E

帘 भ

咅

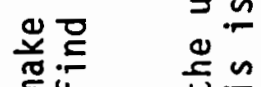

녜 의

ن 잉

வ

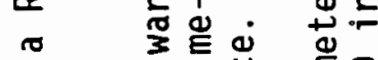

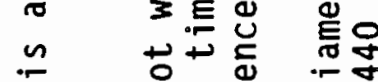

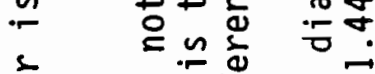

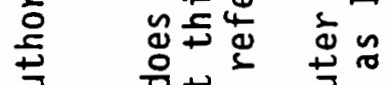

임넝

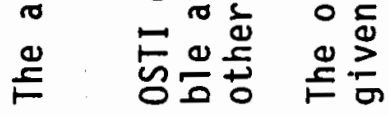

Nin Nin $m$

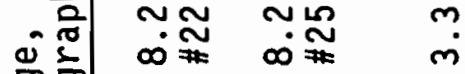

ช్

$\therefore \frac{\pi}{\pi}$

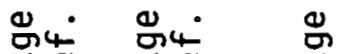

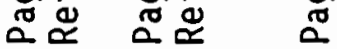

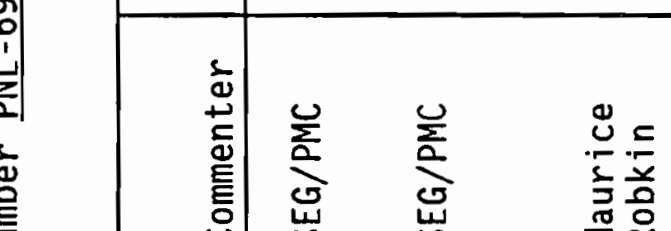

岕 出 $\sum^{\pi}$

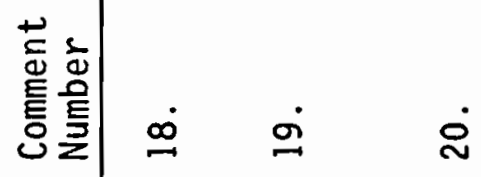




\section{DISTRIBUTION}

No. of

Copies

OFFSITE

18 Technical Steering Panel

D. S. Barth

University of Nevada

4505 Maryland Parkway

Las Vegas, NV 89154

W. A. Bishop

2503 Wedgewood Court SE

01 ympia, WA 98501

M. L. Blazek

Oregon Department of Energy

625 Marion Street N.E.

Salem, OR 97310

G. G. Caldwel1

Director

Tulsa City-County Health Dept

4616 East 15th Street

Tulsa, OK 74112

S. N. Davis

Dept. of Hydrology \& Water Resources

Bldg. 11

University of Arizona

Tucson, AZ 85721

N. J. Germond

224 Iron Mountain Blvd.

Lake Ozwego, OR 97034

P. C. Klingeman

Civil Engineering Dept.

Oregon State University

Corvallis, OR 97331-2302
No. of

Copies

K. J. Kopecky

Fred Hutchinson Cancer

Research Center

1124 Columbia Street

Seatt7e, WA 98104

R. L. Morrill

Dept. of Geography

DP-10

University of Washington

Seattle, WA 98195

A. H. Murphy

c/o Climate Analyses Center

National Weather Service, NOAA

W/NMC51, WWB, Room 604

Washington, DC 20233

V. Nguyen

EWA, Inc.

133 1st Ave. N.

Minneapolis, MN 55401

D. W. Price

Agricultural Economics

Hulbert Hall Room 211

Washington State University

Pullman, WA 99164-6210

M. A. Robkin

Radiological Sciences SB-75

University of Washington

Seattle, WA 98195

G. S. Roessler

Rt. 1, Box 139H

Elysian, MN 56028 
No. of

Copies

B. Shleien

2421 Homestead Drive

Silver Springs, MD 20902

A. P. Slickpoo, Sr.

P. 0. Box 331

809 Nez Perce Lane

Kamiah, ID 83536

J. E. Ti11

Rt. 2 Box 122

Neeses, SC 29107

D. E. Walker, Jr.

P.0. Box 4147

BouTder, CO 80306

2 DOE Office of Scientific and Technical Information

Technical Information Center

P.0. Box 62

Oak Ridge, TN 37830

10 J. S. Stohr

Office of Nuclear Waste Mgmt.

Department of Ecology

99 South Sound Center

Mail Stop PV-11

01ympia, WA 98504
No. of

Copies

ONSITE

DOE Richland Operations

R. F. Brich, SED

A5-55

25 Pacific Northwest Laboratory

M. Y. Ballinger (5) K6-03

W. A. GTass

$\mathrm{K} 1-40$

S. P. Gydesen

$P 8-55$

R. B. Hall

C. M. Heeb

A. H. McMak in

K6-03

$K 6-42$

$\mathrm{K} 6-86$

W. L. Templeton

Project Office Files (5) K6-89

Public Reading Room (5) Al-65

Publishing Coordination $\mathrm{KI}-\mathrm{Il}$

Records Center

$\mathrm{K} 3-70$

Technical Library (2) P8-55 